\title{
Flood Hazard Assessment of 2014 Floods in Sonawari Sub-District of Bandipore District (Jammu \& Kashmir): An application of Geoinformatics
}

\author{
Rajesh Kumar* \\ Centre for the Study of Regional Development, Jawaharlal Nehru University, New Delhi- \\ 110067, India. \\ ${ }^{*}$ Correspondence to: Room No. 209 (Geomorphology Lab.), Centre for the Study of \\ Regional Development, School of Social Sciences, Jawaharlal Nehru University, New \\ Delhi-110067, India. Tel.: +91 9968435902. E-mail address: rajeshcsrd@gmail.com (R. \\ Kumar).
}

\begin{abstract}
Massive flooding in the Kashmir valley was induced by heavy rainfall due to combined effects of western disturbances and Indian summer monsoon during September 04-10, 2014. The populous Sonawari sub-district was severely affected by flood waves that caused complete damage to standing crops and disrupted man-made linear structures (embankment, canal, and road network). High value land use classes (cropped land, built-up and plantation), which encroached on swamps and wetlands between 1972 and 2014, were badly damaged. The main aim of this study is to assess flood hazard at village level in the sub-district. Village-wise standardized flood hazard indicators were flood affected areas, mean turbidity, mean flood depth and duration. These indicators were derived from the Landsat 7 ETM+, Landsat 8 OLI-TIRS images and SRTM $(30 \mathrm{~m})$ DEM. Linear combination of these standardised indicators in GIS environment formulated Flood Hazard Index (FHI). Furthermore, the computed FHI were divided into four zones. Low, moderate, high and very high flood hazard zones occupied 16, 32, 34 and 19 per cent of the total area, respectively. Further, these zones accounted for 21 , 23,33 and 23 per cent of the total number of villages and towns (43), respectively. FHI was validated with overall changes in NDVI values with the help of linear regression model that showed a fair association between village-wise $\mathrm{FHI}$ and changes in mean NDVI values as the coefficient of determination $\left(R^{2}\right)$ was 0.75 with a least standard error of 0.05 . Village-wise flood hazard assessment has immense importance to plan future land use and to implement flood management strategies during pre and post- floods in the sub-district.
\end{abstract}

Keywords: Landsat 8 OLI-TIRS; SRTM (30m); Kashmir valley; Flood hazard index; MNDWI; RMSE 


\section{Introduction}

\subsection{Background}

Natural hazards such as landslide, earthquake, flood, tsunami, forest fire, mud flow and volcanic eruption often cause disruption of physical and cultural environment (Mallinis et al., 2011). Amongst all these natural hazards occurring in the world, floods are considered as the most devastating, frequent and widespread (Sanyal and Lu, 2004; Dhar and Nandargi, 2003). In India, floods are recurrent phenomena mostly in Bihar, Uttar Pradesh, Assam, Odisha and Jammu and Kashmir (Kashmir valley) states. Heavy downpour during monsoonal months (June to September) causes floods in the flood prone areas of these states (Mohapatra and Singh, 2003). On the basis of causal factors, floods in India are of different types namely riverine, dam break, storm surge floods (Rakhecha and Singh, 2009). In Jammu and Kashmir, debris fall in the channel often created flooding by obstructing the natural flow in channels besides rainfall induced riverine flooding. An earthquake induced debris choked Jhelum River near Baramula during 855-883 AD as a consequence, entire Kashmir valley was inundated (Shah, 2015; Bilham and Bali, 2013; Lawrence, 1895). Further, Lawrence (1895) reported about a major flood, occurred in July 1893 due to 52 hours continuous rainfall, which caused damage to 25,426 acres of crop land and 2,225 houses in Jammu and Kashmir. In July 1903, again a major flood occurred; as a consequence, about 7,000 houses were collapsed (Mishra, 2015). Some of major and devastating floods were also reported in the region during 1948, 1950, 1957, 1959, 1969, 1976, 1988, 1992, 2004 , 2010 and 2014 (Meraj et al., 2015a\&b; Mishra, 2015; Bhatt et al., 2011). According to $11^{\text {th }}$ plan working group, the total flood prone areas in India are 45.640 million hectares out of that about 0.514 million hectares lie in Jammu and Kashmir covering $2.3 \%$ of its total geographical area (Planning Commission, 2011).

Riverine flooding occurs as the inflow to a river channel exceeds its capacity to transmit water (Sivasami, 2002). The floodwater beaks or spills over the river banks and inundates the bordering relatively flat and low lying area called floodplain (Benito and Hudson, 2010; Bridge, 2003; Knighton, 1998; Nanson and Croke, 1992; Wolman and 
Leopold, 1957). Flood hazard can be defined as the potential of a given flood that threatens floodplain dwellers' lives and their properties (Smith, 1996). Nature makes floods but floodplain dwellers make flood hazard as they occupy floodplain for shelter, business and agricultural activities, and during floods, these activities often get severely damaged (Singh and Awasthi, 2011; Sivasami, 2002; White et al., 2001; Tobin and Montz, 1997; Smith, 1996; Sears, 1957). Flood protection works (embankments and dowel walls) attract high value land use in flood prone areas but provide false sense of security to floodplain dwellers and their properties therein because these works often get breached during high flood flow ( Sivasami, 2002; UNDP, 1991). On the other hand, these works obstruct flood flow and therefore, cause siltation in river bed, waterlogging and drainage congestion on the countryside and at the confluence of tributaries (RBA, 1980). Siltation in river bed is the main causal factor for breaches in embankments that often cause devastating floods in terms of sand casting as compared to the normal floods (Kumar, 2010).

This is necessary to map flood extent and land use and land cover under flood water during or after massive floods for rapid assessment of flood induced damages (Wang, 2004). Many research works on flood hazard mapping indicate that the maximum water level, flood water velocity and flood duration in a given area are the essential components to evaluate the possible flood induced damages (Merz et al., 2007; Dutta et al., 2003; Todini, 1999). The flood depth above ground level and its extent could be obtained by subtracting the ground elevation from the water surface triangular irregular network (Cook and Merwade, 2009; Schumann et al., 2008; Werner, 2001; UNDP, 1991). Remotely sensed images (Multi-spectral and RADAR) and Digital Elevation Model (DEM) have been used for mapping and quantifying the indicators such as flooded area, flood depth, flood duration, turbid flood water in order to assess the flood hazard (Kumar and Acharya, 2016; Bhatt et al., 2016; Aggarwal, 2015; Manjusree et al., 2015; Patel and Srivastava, 2013; Mallinis et al., 2011; Brisco et al., 2011; Yang et al., 2011; Martinez and Le Toan, 2007; Jain et al., 2006; Xu, 2006; Raclot, 2006; Islam and Sado, 2000; Smith, 1997; Imhoff et al., 1987 ). 


\section{Objectives}

In the backdrop of above mentioned studies, this study has following objectives:

- To analyse district-wise weekly rainfall departure from the normal.

- To find out appropriate Digital Elevation Model (DEM) for flood depth estimation.

- To map the flood hazard variables such as flooded areas, flood depth, turbidity in flood water and to compute flood duration at village level.

- To standardise these flood variables by dividing them with their respective mean in order to compute village-wise Flood Hazard Index (FHI) by simply adding them linearly.

- To validate the $\mathrm{FHI}$ with the help of changes in post and pre-flood mean Normalised Difference Vegetation Index (NDVI) values and damaged length of embankments and road network.

- To map the swamps and wetlands for the periods 1972 and 2014 and to analyse human beings' occupancy therein.

\section{Study area}

Sonawari is a sub-district (Tehsil) of Bandipore district in Jammu and Kashmir State of India (Fig.1). According to Census of India (2011b), the total area of the sub-district is $184 \mathrm{Km}^{2}$ including the area of excluded villages (Malgam and Zani Pora) from this study. Malgam was an uninhabited village while Zani Pora was a flood free village during 2014 floods. Hence, the total area of the studied villages and urban area is 180 $\mathrm{Km}^{2}$. The sub-district comprises 41villages (excluding Malgam and Zani Pora) and two urban areas (Hajin Municipal Corporation (MC) and Sumbal Notified Area Council (NAC)) (Table 1). Asham is a Central Water Commission (CWC) site located at right bank of the Jhelum River for gauge and discharge (G/D) measurements (Fig.1).

\subsection{Geomorphology and hydrometeorology}

Sonawari sub-district of the Bandipore district lies in the Kashmir valley filled with lacustrine (Karewa) deposits such as gravels, pebbles, sand, silt and clay (Ganjoo, 
2014; Dar et al., 2014; Burbank and Johnson, 1983). The sub-district is crisscrossed by sinuous Jhelum River and its anabranching channels. According to Singh (1971), the major geomorphic units of sub-district are rimlands, Jhelum plain and Karewa. Rimlands include the highly dissected hills and valleys of the north-eastern part of the sub-district. Jhelum plain covers piedmont and younger alluvial plains (YAP). Karewa unit includes lacustrine plain, swampy areas, Wular Lake and large sized alluvial islands (Fig.2) (GSI and NRSC, 2005-06).

The Jhelum River comes under zone 1 of hydrogeomorphic zones of India and experiences high and low amount of discharges in monsoon and non-monsoon months, respectively (Kale, 2003) (Fig.3). Mean annual discharge of the Jhelum River at Sangam (33 $47^{\prime} 13.44^{\prime \prime} \mathrm{N}$ and $\left.75^{\circ} 6^{\prime} 17.35 " \mathrm{E}\right)$, Ram Munsi Bagh $\left(34^{\circ} 4^{\prime} 13.85^{\prime \prime} \mathrm{N}\right.$ and $74^{\circ} 49^{\prime} 48.33^{\prime \prime} \mathrm{E}$ ) and Asham sites is $\sim 90, \sim 110$ and $\sim 153 \mathrm{~m}^{3} \mathrm{~s}^{-1}$, respectively. Downstream increase in mean annual discharge is due to tributary influx.

Overall a high rainfall departure from normal was observed in the weeks ending on August 13, September 03-10 and October 08, 2014 (Table 2). However, in the first week of September, the convergence of monsoon and western disturbances along with orographic upliftment caused continuous heavy downpour that in turn produced massive floods in the valley (Kar and Tiwari, 2016; Mishra, 2015; Nandargi and Dhar, 2012). Furthermore, on September 07, 2014, the Jhelum River crossed the danger level at Ram Munsi Bagh site by 2.44 m (CDR, 2015). Meraj et al. (2015b) analysed the frequency of 2014 floods on the basis of historical occurrence of floods in the Kashmir valley. This can be inferred from their study that the return period of 2014 floods is 50 years.

During massive floods of 2014, major parts of alluvial islands and younger alluvial plain were inundated. The non-flooded areas of alluvial islands and younger alluvial plain denote upland (Fig.2). In the sub-district, low lying areas along the left bank of the Jhelum experienced extensive flooding during 2014 floods (e.g. Shah, 2015) (Fig.2). Bed levels of spill channel and Jhelum River along the cross-sections ( $C^{\prime}-C^{\prime}$ and $\left.D^{\prime}-D^{\prime}\right)$ are at higher level than the flooded area (FA) due to siltation therein (Gupta, 2006). 
Hence, flood water spilled over the spill channel and Jhelum River during 2014 floods in south-east part of the sub-district (Fig.4). As a result, the movement of flood water, which was from south-east to north-west direction, followed the general slope of the sub-district. However, the adjoining areas along the Wular Lake were also flooded due to back water effect (Cross-section $\left.A^{\prime}-A^{\prime}\right)$.

\section{Materials and methods}

\subsection{Data used}

The inherent characteristics of multi-spectral remotely sensed data depend on its resolution, amount of cloud cover, cost, easy acquisition, processing and analysis in order to obtain reliable and accurate results (Wang et al., 2002). The spatial resolution of freely available images from Landsat 8 Operational Land Imager and Thermal Infrared Sensor (OLI-TIRS), Landsat 7 Enhanced Thematic Mapper Plus (ETM+) and Landsat 4-5 Thematic Mapper (TM) sensor is better than Landsat 1-5 Multispectral Scanner (MSS), Moderate Resolution Imaging Spectroradiometer (MODIS) and National Oceanic and Atmospheric Administration Advanced Very High Resolution Radiometer (NOAA AVHRR). Hence, in this study, the boundary between flooded and non-flooded areas was drawn efficiently using images from Landsat OLI-TIRS and ETM+ at village level. Furthermore, the combination of Landsat 8 OLI-TIRS and Landsat 7 ETM+ provides 8 days temporal resolution that is good for flood hazard mapping (Kumar and Acharya, 2016; Roy et al., 2014).

In synthetic aperture radar (SAR) images, winds often make ripples in waters of flooded areas. Furthermore, these ripples induce rough water surfaces that have brighter tone in SAR images compared to calm water (Yang et al., 1999). Ripples in flood waters create troubles to demarcate the flooded areas using a universal threshold (Sanyal and Lu, 2004). In addition, speckle filtering methods with good noise removal capabilities often degrade spatial and radiometric resolution of an original SAR image and thus, often cause loss of information extracted from the speckle suppressed image (Qiu et al., 2004). However, such cases are not identical with the cloud free and atmospherically 
corrected Landsat 8 OLI-TIRS and ETM+ images. Hence, reliable and accurate extent of flooded areas and open water bodies can be easily extracted from Landsat images using normalised indices (Kumar and Acharya, 2016; Zhang et al., 2016; Li et al., 2013; Xu, 2006; McFEETERS, 1996).

Landsat $7 \mathrm{ETM}+$, Landsat 8 OLI-TIRS images (30m spatial resolution), Landsat1 MSS (60m spatial resolution) and Shuttle Radar Topographic Mission (SRTM) DEM (30 m spatial resolution) were downloaded from the USGS (2015a) (Table 3). SRTM DEM at spatial resolution of $90 \mathrm{~m}$ (version 4) was downloaded from CGIAR-CSI (2014). The CARTOSAT-1 Digital Elevation Model (CartoDEM) (version 3-R1) and cloud cover image (IRS Resourcesat AWiFS) were downloaded from Bhuwan Indian Geo-platform of ISRO (2016 and 2015). The ASTER Global Digital Elevation Model (ASTER GDEM) (version 2) was downloaded from USGS LP DAAC (2016). Sentinel-2 cloud free multispectral image dated December 03, 2015 (10 m spatial resolution) was obtained from Copernicus (2016). Army Map Service (AMS), Srinagar, edition-1 (1954) (NI-43-6) prepared by Corps of Engineers, Washington DC was also consulted (University of Texas Liberaries, 2016).

Village boundaries of Sonawari Tehsil (sub-district) were obtained from the Administrative Atlas of Jammu and Kashmir (Census of India, 2011a). Village and townwise socio-economic variables such as total population, village/town area (in hectare), number of households, total agricultural labourers, cultivators, household workers were selected from Census of India (2011b). Village-wise total population and number of households were also collected for Sonawari sub-district from Census of India (1971).

\subsection{Atmospheric correction of Landsat ETM+ and Landsat 8 OLI-TIRS images}

The Digital Number (DN) of Landsat 7 (ETM+) and Landsat 8 (OLI-TIRS) images were converted into Top of Atmosphere (TOA) radiance using the multiplicative and additive factors provided in metadata files of these images. TOA radiance of these images was converted into surface reflectance that is essential for the calculation of Modified 
Normalised Difference Water Index (MNDWI) and Normalised Difference Vegetation Index (NDVI). The TOA radiance was computed using the equation (1) (USGS, 2015b).

$R=M_{L}^{*}(D N)+A_{L}$

Where, $\mathrm{R}=\mathrm{TOA}$ radiance $\left(\right.$ Watts $\left./\left(\mathrm{m}^{2}{ }^{*} \mathrm{srad}{ }^{*} \mu \mathrm{m}\right)\right)$

$\mathrm{M}_{\mathrm{L}}=$ Band specific multiplicative rescaling factor

$A_{L}=$ Band specific additive rescaling factor

The radiance images were converted into band-interleaved-by-line (BIL) format and divided by 10 to get the radiance values in $\mu \mathrm{W} /\left(\mathrm{cm} 2{ }^{*}\right.$ srad $\left.{ }^{*} \mathrm{~nm}\right)$ that are further used as input data in the Fast Line-of-sight Atmospheric Analysis of Hypercubes (FLAASH) module of ENVI 5.1 software. FLAASH is a MODTRAN ${ }^{\circledR}$-based radiation transfer code which corrects scattering from atmospheric water vapour, oxygen, carbon dioxide, methane, ozone, molecular and aerosols on the basis of average scene elevation, viewing and solar angles of the scene (Littlefield and Calvin, 2014; Guo and Zeng, 2012; San and Suzen, 2010; Gao et al., 2009; Jensen, 2005; Cooley et al., 2002). The central location of each scene, sensor altitude, flight date and time (GMT) were also put into the FLAASH model as input variables. In this study, aerosol scale height and $\mathrm{CO}_{2}$ mixing ratio were $\sim 1.50 \mathrm{Km}$ and $\sim 390 \mathrm{ppm}$, respectively. The average scene elevation was $\sim 4.2 \mathrm{Km}$. However, Landsat 7 and 8 are multispectral sensors; therefore, the MODTRAN resolution of $\sim 15 \mathrm{~cm}^{-1}$ was selected. The MODTRAN multiscatter model was DISORT with 8 directions.

\subsection{Gap filling of Landsat 7 ETM+ image}

Scan Line Corrector (SLC) of Landsat ETM + sensor failed on May 31, 2003. Therefore, subsequent scenes show line gaps that caused approximately $\sim 22$ per cent data loss. The ETM+ scenes with gaps were converted into surface reflectance using FLAASH. Thereafter, gap filling was performed on ETM+ surface reflectance scenes in ENVI 5.1 software using the triangulation method of Landsat gapfill extension (The Yale Center for Earth Observation, 2013).

4.4 Flooded area extraction and accuracy assessment 
Surface reflectance images of Landsat $7 \mathrm{ETM}+$ and Landsat $8 \mathrm{OLI}$-TIRS were used for inundated area extraction using Modified Normalised Difference Water Index (MNDWI). The formula of MNDWI for Landsat 8 OLI-TIRS is given in equation (2) while for Landsat $7 \mathrm{ETM}+$ in equation (3) $(\mathrm{Xu}, 2006)$.

[(Green-SWIR1) / (Green+SWIR1)]

[(Band2-Band5) / (Band2 + Band5)]

MNDWI index values vary from -1 to +1 . Positive values of the index show flooded/inundated areas while the negative values denote non-flooded areas $(\mathrm{Xu}$, 2006).

An accuracy assessment of flooded and non-flooded areas of September 10, 2014 was accomplished by selecting the random reference points of these areas from Google Earth (GE) that provides cost free high resolution reference images of the same date (e.g. Kibret et al., 2016; Olofsson et al., 2014; Fonji and Taff, 2014). A sum of 31 random reference points was generated for accuracy assessment. Overall accuracy of these areas was $\sim 87.09$ per cent with a Kappa coefficient of $\sim 0.74$ (Table 4 ).

Actual flooded area was obtained by subtracting the area of pre-flood water bodies (August 25, 2014) from total flooded area on different dates. Village wise actual flooded area was calculated using clip and spatial join analysis tools of ARC GIS 10. A proportion of actual flooded area in each village was obtained by dividing the actual flooded area in a village with the total area of that particular village.

\subsection{Turbidity in flood water}

In this study, MNDWI values were taken as proxy to turbidity in the flood water. High MNDWI values show high turbid water while the low MNDWI values denote low turbid water (e.g. $\mathrm{Xu}, 2006$ ). High turbid water has high potential for damaging crops, plantation and aquatic habitats of swampy areas as compared to the less turbid water. 
Village wise mean turbidity was calculated using the extraction tool of spatial analyst of ARC GIS 10.

4.6 DEMs accuracy assessment and flood depth estimation

An elevation accuracy of SRTM (spatial resolution of $90 \mathrm{~m}$ and $30 \mathrm{~m}$ ), ASTER and CARTOSAT-1 DEMs was checked with the spot heights extracted from the Survey of India (Sol) topographical sheets in order to select an appropriate and a relatively accurate DEM for flood depth estimation in the actual flooded areas of Sonawari subdistrict (Fig.5). Root Mean Square Error (RMSE) of each DEM was computed using equation (4) (Schumann et al., 2008).

$\mathrm{RMSE}_{\mathrm{DEM}}=\sqrt{\frac{\sum_{i=1}^{n}\left(E_{R_{i}}-E_{\mathrm{DEM}_{i}}\right)^{2}}{n}}$

Where, $E_{R}$ denotes reference elevation data (topographical sheet spot heights), $E_{D E M}$ is elevation data of different DEMs and $\mathrm{n}$ is total number of reference data points.

The computed RMSE values for SRTM (90m), SRTM (30m), ASTER and CARTOSAT-1 DEMs were 1.3, 1.1, 7.9 and 36.1 metres, respectively. Absolute maximum elevation error values for SRTM (90m), SRTM (30m), ASTER and CARTOSAT-1 DEMs were 3.0, 2.0, 17.0 and 39.9 metres, respectively. The RMSE and absolute maximum elevation error values for SRTM (30 m) DEM were least. Hence, this DEM was selected for flood depth estimation.

The maximum flood extent in Sonawari sub-district occurred on September10 and 18, 2014. Landsat $8 \mathrm{OLI}$ and landsat $7 \mathrm{ETM}+$ images of these periods were selected to draw 21 transects perpendicular to the flooded areas using ARC GIS 10. Further, a sum of 190 points along all transects was drawn at regular interval.

Edge points on all transects showed highest flood level (HFL) therefore the ground elevation of all points were subtracted from their respective HFL to obtain the flood 
depth in metre above ground level (Fig.6) (e.g. UNDP, 1991). Later on, flood depth values of these points were selected as input for Inverse Distance Weighting (IDW) interpolator method of ARC GIS 10 which in turn provided raster layer of flood depth in actual flooded areas at $30 \mathrm{~m}$ spatial resolution. Village wise mean flood depth (in metre) was computed using the extraction tool of spatial analyst of ARC GIS 10.

\subsection{Flood duration mapping}

Flood duration was analyzed using locational probability model (Graf, 2000). The locational probability model works on the overlaying (adding function) of different flood layers which have certain numerical weights (W). A weightage value of each flood layer was derived using equation (5). A zero probability for the layer of September 07, 2014 was assumed as the entire valley was obscured by clouds (Fig.7).

$W=(t / m)$

Where, $\mathrm{t}$ represents number of days separating the two flood layers. $\mathrm{m}$ denotes total number of days of inundated layers.

For example, an assigned weight of September 26, 2014 flood layer was 0.23 because of 8 days separating duration of the September 26, 2014 layer from that taken on September 18, 2014 (Table 5 ).

Final locational probability (p) was assigned using the equation (6) in ARC GIS 10.

$p=[(W$ September 10 $)+(W$ September 18 $)+(W$ September 26 $)+(W$ October 04 $)+(W$ October 12)]

Flood duration (in days) in actual flooded areas was obtained using the equation (7).

Flood duration $=(\mathrm{p} \times \mathrm{m})$

Later on, village wise mean flood duration (in days) was computed using the extraction tool of spatial analyst of ARC GIS 10.

4.8 Flood hazard index 
Actual flooded areas, turbidity in flood water, flood depth and duration are the key indicators for flood hazard assessment. The combined effects of these indicators cause damage to natural as well as cultural environment of the earth surface. Therefore, in this study these indicators were standardised by dividing them with their respective mean for fair comparison and formulation of composite index. Later on, a linear combination of standardised values of these indicators produced a village wise Flood Hazard Index (FHI) using equation (8) (Fig. 8).

$\mathrm{FHI}=\left(\mathrm{A}+\mathrm{T}+\mathrm{FD}_{1}+\mathrm{FD}_{2}\right) \ldots \ldots \ldots \ldots(8)$

Where, A denotes village wise standardised proportion of actual flooded areas.

T shows village wise standardised mean turbidity in flood water

$\mathrm{FD}_{1}$ indicates villages wise standardised mean flood depth

$\mathrm{FD}_{2}$ shows villages wise standardised mean flood duration.

After analysing the histogram of the $\mathrm{FHI}$, natural breaks classification method was used to show clustering of villages in different flood hazard zones. This classification method marks out break points between classes by assessing the inherent natural clustering of input data (Osaragi, 2002; Minami, 2000).

\subsection{Normalised difference vegetation index}

NDVI values show health of vegetation. The surface reflectance images of NearInfrared (NIR) and Red bands of Landsat 7 ETM + and Landsat 8 OLI sensor were used for NDVI computation. NDVI was calculated using the equation (9) (Jensen, 2005).

NDVI $=[(N I R-R e d) /(N I R+R e d)]$

Since village wise flood damage statistics (in monetary terms) of damaged houses, crops and public utilities are not yet available, changes in village-wise mean NDVI values between post and pre-flood period were taken as a proxy of flood induced damage to crops and plantation. The overall changes in village-wise mean NDVI values were selected to validate the computed flood hazard index with the help of linear regression model. 


\subsection{Wetland and swampy area mapping}

Wetland and swampy area mapping in inhabited villages was done using the visual interpretation of Landsat MSS and Landsat 8 OLI-TIRS images. Resampling of Landsat 8 OLI-TIRS image (30 m spatial resolution) was performed at $60 \mathrm{~m}$ of spatial resolution in order to match the pixel size of this image with Landsat MSS. Further, on-screen digitization was performed on 1:80K scale to trace out wetlands and swampy areas using ARC GIS 10.

\subsection{Embankments, road network and canal mapping}

These public works/utilities were mapped using AMS topographical sheet, PAN band of Landsat 8 OLI-TIRS (15 m spatial resolution) and Sentinel-2 multispectral image (false colour composite band combination 8, 4 and 3) (10 m spatial resolution). Visual interpretation coupled with on-screen digitization was done to trace these linear manmade features. The turbid flood water flow across these features denotes breaches. Further, overlay method such as clipping of these works with actual flooded area layer was accomplished to spot damaged and overtopping portions using ARCGIS 10.

\subsection{Pre-flood land use and land cover mapping}

Decision tree classification method was applied to prepare land use and land cover map of the flood affected areas using the pre-flood image (Landsat8 OLI-TIRS) dated August 25,2014 . Band differentiation, band thresholding and band ratioing techniques based on histogram distribution of radiance values of Landsat 8 OLI-TIRS image were the basis for generating decision rules (Fig. 9). A sum of 97 random reference points was generated from high resolution image of GE for accuracy assessment. Overall accuracy of different land use and land cover classes was $\sim 82.47$ per cent with a Kappa coefficient of $\sim 0.78$ (Table 6 ).

\section{Results and discussion}


Total actual flooded area was $\sim 76 \mathrm{Km}^{2}$ that was computed using the union function of flooded polygon layers of different flood periods. Overall 42 per cent area of the subdistrict was actually flooded. The range of actual flooded areas was between $13 \mathrm{Km}^{2}$ and $67 \mathrm{Km}^{2}$ (Table 7). Due to heavy downpour in the first week of September 2014, the sub-district was hit by a massive flood on September 10, 2014 when almost $45 \mathrm{Km}^{2}$ areas were submerged. However, the downstream movement of flood waves further accentuated flooding situation in the sub-district (especially in Hajin (MC), Sumbal (NAC), Gund Famzen, Pushwari, Markundal, Amcha Kundal, Vijpora, Gund Bun, Naid Khai, Gund Balakh, Shah Gund and Gundi Jahangir villages). As a consequence, 67 $\mathrm{Km}^{2}$ of area was inundated on September 18, 2014. Flood water receded after September 26, 2014 (Table 7). The proportion of actual flooded area to the total village area was highest in Tirgam village while the lowest was observed in Chiva village.

In actual flooded areas of Sonawari sub-district, flood depth varied between $0.5 \mathrm{~m}$ to 8.5 $\mathrm{m}$ above the ground level while the estimated mean flood depth was $2.81 \mathrm{~m}$ above the ground level during maximum flood extent (September 10 and 18, 2014) (Table 8). The highest estimated mean flood depth was observed in Naid Khai (the term 'Khai' denotes low lying area) while the lowest in Najin village.

In the sub-district, a large chunk (53 per cent) of cropped land was affected by the floods of 2014. Flood affected built-up and plantation/forest areas covered 1 per cent and 3 per cent of the total inundated area, respectively (Table 9 and Fig.10). Overall negative changes in mean NDVI values during post flood were 60 per cent as compared to pre flood (Table 10). The negative changes in mean NDVI values in the flooded cropped land and in plantation/forest areas were 63 per cent and 40 per cent, respectively (Table 11-12). Cropped land (rice and maze) and orchards were severely damaged by the turbid and lingered flood water (JKCCS, 2015). Turbidity in flood water was caused by heavy downpour induced erosion in the fragile upper reaches and floodplain of the Jhelum River (e.g. Gupta, 2006). The highest mean turbidity was observed on September 10, 2014 while the lowest was on October 04, 2014 (Table 7). Flood duration in the sub-district varied from 3 to 35 days. The mean flood duration was 
of 19 days. Highest mean flood duration was observed in Tirgam village while the lowest was in Shadi Pora village.

The computed $\mathrm{FHI}$ were divided into four zones. Low, moderate, high and very high flood hazard zones occupied 16, 32, 34 and 19 per cent of the total area, respectively. Further, these zones accounted for 21, 23, 33 and 23 per cent of the total number of villages and towns (43), respectively (Table 13 and Fig. 11). Overall population density in the sub-district is 958 person $/ \mathrm{Km}^{2}$ which is considerably higher than the population density of Jammu and Kashmir (56 person/ $/ \mathrm{Km}^{2}$ ) and India (368 person/ $/ \mathrm{Km}^{2}$ ) (Census of India, 2011c). The Population density is decreasing with respect to the increasing $\mathrm{FHI}$ values (Table 13). This signifies that people of Sonawari sub-district are aware of the hazardous areas.

\subsection{Validation of $\mathrm{FHI}$}

FHI was validated with overall changes in NDVI values with the help of linear regression model which showed a fair association between $\mathrm{FHI}$ values and changes in NDVI values as the coefficient of determination $\left(R^{2}\right)$ was 0.75 with a least standard error of 0.05 (Fig. 12). Cultivators, agricultural labourers and household workers (including main and marginal) account for 25.4 per cent, 20 per cent and 23 per cent of the total workers in the study area of the sub-district, respectively (Census of India, 2011b). The socioeconomic condition of these workers depends upon the products/outputs from the cropped, forest and plantation areas. Flood induced damages to these areas during 2014 floods could have affected the livelihood of these workers in the sub-district.

Man made structures (embankments, road network and canals) obstruct lateral and longitudinal connectivity of sediment and flood water fluxes in the floodplain (Kumar et. al. 2014). As a consequence, such obstructions cause waterlogging and prolonged floods in the floodplain (Kumar et al., 2014; Pandey et al., 2012). These structures often experience overtopping, breaches and lateral erosion during high flood flows. In Sonawari sub-district, embankments are the main structural measures for flood control. In flooded areas, embankments, road network and canals were severely damaged due 
to laterally erosion, overtopping and breaches (Figs. 13, $14 \& 15$ ) that in turn caused local scour and further led to increase in turbidity in flood water. Generally, these structures (except canal) have experienced increasing trends in damaged length with respect to increasing $\mathrm{FHI}$ values (Table 14). Such trends also validate the FHI.

\subsection{Encroachment on wetlands/swamps}

Wetland and swampy areas, which are defined as vegetated depressions in the active and older floodplain, often receive flood water from the main channel during monsoon season (Charlton, 2008). These areas are classified as natural detention basins (Planning Commission, 2011).

In the sub-district, total number of households increased by 186 per cent while the total population increased by 207 per cent between 1971 and 2011. However, the wetlands and swampy areas shrank by 29 per cent between October 30, 1972 and August 25, 2014 (Fig.16). A negative association between changes in village-wise total population (1971-2011) and wetlands/swampy areas (October 30, 1972 -August 25, 2014) shows a Pearson correlation coefficient of -0.38 which is significant at 0.05 level. In other words, decreasing area under wetland and swamp signifies human beings' occupancy therein. Besides anthropogenic factor, some other factors such as trends in rainfall, frequency of inundation, rate of siltation and the ground water level, which also often affect wetlands and swampy areas, can be also assessed well in advance to draw a concrete conclusion. This would be a futuristic scope of the study.

Recent land use and land cover pattern (August 25, 2014) in wetlands and swampy areas of October 30, 1972 shows that about 44 per cent of the total area is under cropped land. Plantation/forest and built-up areas occupy 11 and 2 per cent of the total area, respectively (Fig.17). Such land use and land cover signifies human beings' occupancy therein. Waste land and water bodies collectively cover 43 per cent of area (Table 15). Such types of land use/land cover pattern in wetlands and swamps have also been reported in the Kashmir valley (Kuchay et al., 2016; Romshoo and Rashid, 2014; Mushtaq and Pandey, 2013; Joshi et al., 2002). The area under natural detention 
basins should not be encroached on by high value land use such as built-up, plantation and cropped land in order to minimise flood damage.

\section{Conclusion}

The heavy rainfall was caused by combined effects of western disturbances and Indian summer monsoon during $4^{\text {th }}-10^{\text {th }}$ September, 2014 in the Kashmir valley as the rainfall departure from normal varied between 168 per cent and 1489 per cent. Such intense rainfall caused enormous surface runoff along with high water level in the Jhelum River, Spill and anabranching channels resulting into overtopping and breaches in embankments and road network. As a consequence, 42 per cent area of the Sonawari sub-district was inundated. SRTM (30 m) DEM is found to be appropriate for flood depth estimation because of its low RMSE compared to other DEMs. The flood hazard assessment specifically based on the village-wise variability in flooded areas, turbidity in flood water, flood depth and duration. Overall highly turbid flood water, high flood depth (2.8m) and prolonged flood duration (19 days) caused crop failure in the sub-district. Area under Swamps and wetlands shrank by 29 per cent between 1972 and 2014 due to human beings' occupancy therein. In terms of aerial coverage of flooding, damaged crops and man-made linear structures; the 2014 floods in the densely populated subdistrict was a high magnitude flood.

The standardised indicators used for formulation of $\mathrm{FHI}$ can be applied in any part of the world for flood hazard assessment. The present study would have immense importance for planning future land use in the flooded areas and for making proper arrangement to evacuate the stranded population from very high, high and moderate flood hazard zones. A considerable length of embankments and roads was submerged and damaged during the maximum flood extent therefore; real time flood warning message dissemination system coupled with a proper arrangement of boats in moderate, high and very high flood zones can be an appropriate measure to evacuate people from these zones during floods. The encroachment on wet lands should be restricted by law enforcement in order to minimise flood induced damage to high value land use such as crop land, built up and plantation. 


\section{Acknowledgments}

RK is thankful to USGS for providing Landsat images and SRTM DEMs at no cost. RK is also grateful to the anonymous reviewer for his illuminating and insightful comments.

\section{References}

Aggarwal, A., 2015. Exposure, hazard and risk mapping during a flood event using open source geospatial technology. Geomatics, Nat. Hazards Risk 7, 1426-1441. doi:10.1080/19475705.2015.1069408

Benito, G., Hudson, P.F., 2010. Flood hazards: the context of fluvial geomorphology. In: Alcántara-Ayala, I., Goudie, A.S., (Eds.) Geomorphological hazards and disaster prevention. Cambridge University Press, pp. 111-128. doi:10.1017/CBO9780511807527.010

Bhatt, C.M., Rao, G.S., Farooq, M., Manjusree, P., Shukla, A., Sharma, S.V.S.P., Kulkarni, S.S., Begum, A., Bhanumurthy, V., Diwakar, P.G., Dadhwal, V.K., Rao, G.S., Farooq, M., Manjusree, P., Shukla, A., Sharma, S.V.S.P., 2016. Satellitebased assessment of the catastrophic Jhelum floods of September 2014 , Jammu \& Kashmir , India. Geomatics, Nat. Hazards. doi:10.1080/19475705.2016.1218943

Bhatt, C.M., Rao, G.S., Manjusree, P., Bhanumurthy, V., 2011. Potential of high resolution satellite data for disaster management: a case study of Leh, Jammu \& Kashmir (India) flash floods, 2010. Geomatics, Nat. Hazards Risk 2, 365-375. doi:10.1080/19475705.2011.580014

Bhuwan Indian Geo-platform of ISRO, 2016. NRSC/ISRO open data and product archive facilitates. http://bhuvan.nrsc.gov.in/data/download/index.php (accessed 23.01.2016).

Bhuwan Indian Geo-platform of ISRO, 2015. Cloud cover image of Kashmir valley. http://bhuvan-noeda.nrsc.gov.in/disaster/disaster/disaster.php\# (accessed 10.02. 2015) 
Bilham, R., Bali, B.S., 2013. A ninth century earthquake-induced landslide and flood in the Kashmir Valley, and earthquake damage to Kashmir's Medieval temples. Bull. Earthq. Eng. 1-31. doi:10.1007/s10518-013-9504-x

Bridge, J.S., 2003. Rievrs and Floodplains: Forms, Processes and Sedimentary Record. Blackwell, Oxford.

Brisco, B., Schmitt, A., Murnaghan, K., Kaya, S., Roth, A., 2011. SAR polarimetric change detection for flooded vegetation. Int. J. Digit. Earth 6, 1-12. doi:10.1080/17538947.2011.608813

Burbank, D.W., Johnson, G.D., 1983. The late cenozoic chronologic and stratigraphic development of the Kashmir intermontane basin, Northwestern Himalaya. Palaeogeogr. Palaeoclimatol. Palaeoecol. 43, 205-235. doi:10.1016/00310182(83)90012-3

CDR, 2015. Retrospective and Prospective of 2014 Floods For Building Flood Resilient Kashmir. http://www.cdrindia.org/retrospective_and_Prospective_of_2014_Floods_15.pdf . (accessed 10.04.2016).

Charlton, R., 2008. Fundamentals of fluvial geomorphology. Routledge, London.

Census of India, 1971. District Census Handbook of Baramula. Parts X-A\&B, town and village directory, village and town-wise primary census abstract, Director of Census Operations, Jammu and Kashmir.

Census of India, 2011a. Administrative atlas of Jammu and Kashmir. http://censusindia.gov.in/2011census/maps/atlas/Jammu\%20and\%20kashmir.html (accessed 23.02.2016).

Census of India, 2011b. District census handbook of Bandipore. Village and town wise primary census abstract, series 02 , part XII B, Directorate of Census Operations, Jammu and Kashmir. 
http://www.censusindia.gov.in/2011census/dchb/0109_PART_B_DCHB_BANDIPOR E.pdf. (accessed 23.03.2016).

Census of India, 2011c. Primary census abstract of India and Jammu and Kashmir. http://www.censusindia.gov.in/pca/default.aspx. (accessed 10.04.2016).

CGIAR-CSI, 2014. SRTM 90m digital elevation data. http://srtm.csi.cgiar.org/ (accessed 12.12.2014).

Cook, A., Merwade, V., 2009. Effect of topographic data, geometric configuration and modeling approach on flood inundation mapping. J. Hydrol. 377, 131-142. doi:10.1016/j.jhydrol.2009.08.015

Cooley, T., Anderson, G.P., Felde, G.W., Hoke, M.L., Ratkowski, A.J., Chetwynd, J.H., Gardner, J.A., Adler-Golden, S.M., Matthew, M.W., Berk, A., Bernstein, L.S., Acharya, P.K., Miller, D., Lewis, P., 2002. FLAASH, a MODTRAN4-based atmospheric correction algorithm, its application and validation, in: IEEE International Geoscience and Remote Sensing Symposium. pp. 1414-1418. doi:10.1109/IGARSS.2002.1026134

Copernicus, 2016. Sentinels scientific data hub. https://scihub.copernicus.eu/dhus/\#/home (accessed 23.01.2016).

Dar, R.A., Romshoo, S.A., Chandra, R., Ahmad, I., 2014. Tectono-geomorphic study of the Karewa Basin of Kashmir Valley. J. Asian Earth Sci. 92, 143-156. doi:10.1016/j.jseaes.2014.06.018

Dhar, O.N., Nandargi, S., 2003. Hydrometeorological aspects of floods in India. Nat. Hazards 28, 1-33. doi:10.1023/A:1021199714487

Dutta, D., Herath, S., Musiake, K., 2003. A mathematical model for flood loss estimation. J. Hydrol. 277, 24-49. doi:10.1016/S0022-1694(03)00084-2 
Fonji, S.F., Taff, G.N., 2014. Using satellite data to monitor land-use land-cover change in North-eastern Latvia. Springerplus 3, 61. doi:10.1186/2193-1801-3-61

Ganjoo, R.K., 2014. The vale of Kashmir: landform evolution and processes. In: Kale, V.S., (Ed.) Landscapes and landforms of India. Springer, Dordrecht, pp. 125-133.

Gao, B.C., Montes, M.J., Davis, C.O., Goetz, A.F.H., 2009. Atmospheric correction algorithms for hyperspectral remote sensing data of land and ocean. Remote Sens. Environ. 113, S17-S24. doi:10.1016/j.rse.2007.12.015

Graf, W.L., 2000. Locational probability for a dammed, urbanizing stream: Salt River, Arizona, USA. Environ. Manage. 25, 321-335. doi:10.1007/s002679910025

GSI, NRSC, 2005-06. Geomorphology and Lineament NGLM, Landform, 50K, Jammu and Kashmir. http://bhuvan.nrsc.gov.in/gis/thematic/index.php. (accessed 10.02.15).

Guo, Y., Zeng, F., 2012. Atmospheric Correction Comparison of Spot-5 Image Based on Model Flaash and Model Quac. ISPRS - Int. Arch. Photogramm. Remote Sens. Spat. Inf. Sci. XXXIX-B7, 7-11. doi:10.5194/isprsarchives-XXXIX-B7-7-2012

Gupta, R.D., 2006. Environmental Pollution: Hazards and Control. Concept Publishing Company, New Delhi.

Imhoff, M.L., Vermillion, C., Story, M.H., Choudhary, A.M., Gafoor, A., Polcyn, F., 1987. Monsoon Flood Boundary Delineation and Damage Assessment Using Space Borne Imaging Radar and Landsat Data. Photogramm. Eng. Remote Sens. 53, 405-413.

Islam, M., Sado, K., 2000. Flood hazard assessment in Bangladesh using NOAA AVHRR data with geographical information system. Hydrol. Process. 14, 605- 620.

Jain, S.K., Saraf, A.K., Goswami, A., Ahmad, T., 2006. Flood inundation mapping using NOAA AVHRR data. Water Resour. Manag. 20, 949-959. doi:10.1007/s11269-0069016-4 
Jensen, J.R., 2005. Introductory Digital Image Processing:A Remote Sensing Perspective, third ed. Pearson Prentice Hall, Upper Saddle River, NJ.

JKCCS, 2015. Occupational hazard: the Jammu and Kashmir floods of September 2014 . http://www.jkccs.net/wp-content/uploads/2015/04/Occupation-HazardJKCCS.pdf. (accessed 10.04.2016).

Joshi, P.K., Rashid, H., Roy, P.S., 2002. Landscape dynamics in Hokersar Wetland, Jammu \& Kashmir-An application of geospatial approach. J. Indian Soc. Remote Sens. 30, 1-5. doi:10.1007/BF02989971

Kale, V.S., 2003. Geomorphic effects of monsoon floods on Indian rivers. Nat. Hazards 28, 65-84. doi:10.1023/A:1021121815395

Kar, S.C., Tiwari, S., 2016. Model simulations of heavy precipitation in Kashmir, India, in September 2014. Nat. Hazards 81, 167-188. doi:10.1007/s11069-015-2073-3

Kibret, K.S., Marohn, C., Cadisch, G., 2016. Assessment of land use and land cover change in South Central Ethiopia during four decades based on integrated analysis of multi-temporal images and geospatial vector data. Remote Sens. Appl. Soc. Environ. 3, 1-19. doi:10.1016/j.rsase.2015.11.005

Kinghton, D., 1998. Fluvial Forms and Processes. Arnold, London.

Kuchay, N.A., Bhat, M.S., Shafi, N., 2016. Population growth , urban expansion and housing scenario in Srinagar City, J\&K, India. J. Geogr. Regional Plann. 9, 1-11. doi:10.5897/JGRP2015.0506

Kumar, R., 2010. Fluvial processes in lower Rapti river basin: a case study of impacts on arable land. Centre for the Study of Regional Development, Jawaharlal Nehru University, New Delhi, India, Ph.D thesis. 
Kumar, R., Jain, V., Prasad Babu, G., Sinha, R., 2014. Connectivity structure of the Kosi megafan and role of rail-road transport network. Geomorphology 227, 73-86. doi:10.1016/j.geomorph.2014.04.031

Kumar, R., Acharya, P., 2016. Flood hazard and risk assessment of 2014 floods in Kashmir Valley : a space-based multisensor approach. Nat. Hazards 84, 437-464. doi:10.1007/s11069-016-2428-4

Lawrence, W.R., 1895. The valley of Kashmir. Asian Educational Services, New Delhi.

Li, W., Du, Z., Ling, F., Zhou, D., Wang, H., Gui, Y., Sun, B., Zhang, X., 2013. A comparison of land surface water mapping using the normalized difference water index from TM, ETM+ and ALI. Remote Sens. 5, 5530-5549. doi:10.3390/rs5115530

Littlefield, E.F., Calvin, W.M., 2014. Geothermal exploration using imaging spectrometer data over Fish Lake Valley, Nevada. Remote Sens. Environ. 140, 509-518. doi:10.1016/j.rse.2013.09.007

Mallinis, G., Gitas, I.Z., Giannakopoulos, V., Maris, F., Tsakiri-Strati, M., 2011. An object-based approach for flood area delineation in a transboundary area using ENVISAT ASAR and LANDSAT TM data. Int. J. Digit. Earth 8947, 1-13. doi:10.1080/17538947.2011.641601

McFEETERS, S.K., 1996. The use of the Normalized Difference Water Index (NDWI) in the delineation of open water features. Int. J. Remote Sens. 17, 1425-1432. doi:10.1080/01431169608948714

Manjusree, P., Bhatt, C.M., Begum, A., Rao, G.S., Bhanumurthy, V., 2015. A decadal historical satellite data analysis for flood hazard evaluation: A case study of Bihar (North India). Singap. J. Trop. Geogr. 36, 308-323. doi:10.1111/sjtg.12126

Martinez, J.M., Le Toan, T., 2007. Mapping of flood dynamics and spatial distribution of vegetation in the Amazon floodplain using multitemporal SAR data. Remote Sens. 
Environ. 108, 209-223. doi:10.1016/j.rse.2006.11.012

Meraj, G., Romshoo, S.A., Yousuf, A.R., Altaf, S., Altaf, F., 2015a. Assessing the influence of watershed characteristics on the flood vulnerability of Jhelum basin in Kashmir Himalaya. Nat. Hazards 77, 153-175. doi:10.1007/s11069-015-1605-1

Meraj, G., Romshoo, S.A., Yousuf, A.R., Altaf, S., Altaf, F., 2015b. Assessing the influence of watershed characteristics on the flood vulnerability of Jhelum basin in Kashmir Himalaya: reply to comment by Shah 2015. Nat hazards, 78, 1-5. Doi $10.1007 / \mathrm{s} 11069-015-1861-0$

Merz, B., Thieken, A., Gocht, M., 2007. Flood Risk Mapping at the Local Scale: Concepts and Challenges. Flood risk management in Europe, pp. 231-251.

Minami, M., 2000. Using ArcMap: GIS by ESRI. Environmental System Research Institute, Redlands.

Mishra, A.K., 2015. A study on the occurrence of flood events over Jammu and Kashmir during September 2014 using satellite remote sensing. Nat. Hazards 78, 14631467. doi:10.1007/s11069-015-1768-9

Mohapatra, P.K., Singh, R.D., 2003. Flood management in India. Nat. Hazards 28, $131-$ 143. doi:10.1023/A:1021178000374

Mushtaq, F., Pandey, A.C., 2013. Assessment of land use/land cover dynamics vis-àvis hydrometeorological variability in Wular Lake environs Kashmir Valley, India using multitemporal satellite data. Arab. J. Geosci. 7, 4707-4715. doi:10.1007/s12517-013-1092-1

Nandargi, S., Dhar, O.N., 2012. Extreme Rainstorm Events over the Northwest Himalayas during 1875-2010. J. Hydrometeorol. 13, 1383-1388. doi:10.1175/JHMD-12-08.1 
Nanson, G.C., Croke, J.C., 1992. A genetic classification of floodplains. Geomorphology 4, 459-486.

Olofsson, P., Foody, G.M., Herold, M., Stehman, S. V., Woodcock, C.E., Wulder, M.A., 2014. Good practices for estimating area and assessing accuracy of land change. Remote Sens. Environ. 148, 42-57. doi:10.1016/j.rse.2014.02.015

Osaragi, T., 2002. Classification methods for spatial data representation. http//www.casa.ucl.ac.uk/paper40.pdf. (accessed 06.04.2016).

Pandey, A. C., Singh, S.K., Nathawat, M.S., 2012. Analysing the impact of anthropogenic activities on waterlogging dynamics in Indo-Gangetic Plains, northern Bihar, India. Int. J. Remote Sens. 33, 135-149. doi:10.1080/01431161.2011.584916

Patel, D.P., Srivastava, P.K., 2013. Flood Hazards Mitigation Analysis Using Remote Sensing and GIS: Correspondence with Town Planning Scheme. Water Resour. Manag. 27, 2353-2368. doi:10.1007/s11269-013-0291-6

Planning Commission, 2011. Report of Working Group on Flood Management and Region Specific Issues for XII plan. Govt. of India, New Delhi.

Qiu, F., Berglund, J., Jensen, J.R., Thakkar, P., Ren, D., 2004. Speckle Noise Reduction in SAR Imagery Using a Local Adaptive Median Filter. GIScien Remote Sens. 41, 244-266.

Raclot, D., 2006. Remote sensing of water levels on floodplains: a spatial approach guided by hydraulic functioning. Int. J. Remote Sens. 27, 2553-2574. doi:10.1080/01431160600554397

Rakhecha, P., Singh, V.P., 2009. Applied Hydrometeorology. Concept Publishing Company, New Delhi.

RBA, 1980. Report on national commission on floods (India). Ministry of Energy and Irrigation, New Delhi. 
Romshoo, S.A., Rashid, I., 2014. Assessing the impacts of changing land cover and climate on Hokersar wetland in Indian Himalayas. Arab. J. Geosci. 7, 143-160. doi:10.1007/s12517-012-0761-9

Roy, D.P., Wulder, M.A., Loveland, T.R., C.E., W., Allen, R.G., Anderson, M.C., Helder, D., Irons, J.R., Johnson, D.M., Kennedy, R., Scambos, T.A., Schaaf, C.B., Schott, J.R., Sheng, Y., Vermote, E.F., Belward, A.S., Bindschadler, R., Cohen, W.B., Gao, F., Hipple, J.D., Hostert, P., Huntington, J., Justice, C.O., Kilic, A., Kovalskyy, V., Lee, Z.P., Lymburner, L., Masek, J.G., McCorkel, J., Shuai, Y., Trezza, R., Vogelmann, J., Wynne, R.H., Zhu, Z., 2014. Landsat-8: Science and product vision for terrestrial global change research. Remote Sens. Environ. 145, 154-172. doi:10.1016/j.rse.2014.02.001

San,B.T., Suzen, M.L., 2010. Evaluation of Different Atmospheric Correction Algorithms for Eo-1 Hyperion Imagery. Int. Arch. Photogramm. Remote Sens. Spat. Inf. Sci. XXXVIII, 392-397.

Sanyal, J., Lu, X.X., 2004. Application of remote sensing in flood management with special reference to monsoon Asia: A review. Nat. Hazards 33, 283-301. doi:10.1023/B:NHAZ.0000037035.65105.95

Schumann, G., Matgen, P., Cutler, M.E.J., Black, A., Hoffmann, L., Pfister, L., 2008. Comparison of remotely sensed water stages from LiDAR, topographic contours and SRTM. ISPRS J. Photogramm. Remote Sens. 63, 283-296. doi:10.1016/j.isprsjprs.2007.09.004

Sears, P.B., 1957. Natural and Cultural Aspects of Floods. Science 125, 806-807.

Shah, A.A., 2015. Assessing the influence of watershed characteristics on the flood vulnerability of Jhelum Basin in Kashmir Himalaya by Gowhar et al., 2015. Nat. Hazards 77, 2139-2143, doi: 10.1007/s11069-015-1775-x 
Showkat, S., Dar, A.Q., Faizan, M., Haq, U., 2014. Temporal Assessment of Water Quality of River Jhelum Using Parametric and Non-Parametric Methods. IOSR J. Mech. Civ. Eng. (IOSR-JMCE) 2014, 6-12.

Singh, D. S., Awasthi, A., 2011. Natural hazards in the Ghaghara River area, Ganga Plain, India. Nat. Hazards 57, 213-225. doi:10.1007/s11069-010-9605-7

Singh, R.L. 1971. India: a regional geography, NGSI, Varanasi.

Sivasami, K.S., 2002. Environmental effect due to floods and reservoirs. In: Subramanian, V., (Ed.) Environmental Hazard in South Asia. Capital Publishing Company, New Dehli, pp. 65-82.

Smith, K., 1996. Environmental hazards: assessing risk and reducing disaster, second ed. Routledge, London.

Smith, L.C., 1997. Satellite remote sensing of river inundation area, stage, and discharge: A review. Hydrol. Process. 11, 1427-1439. doi:10.1002/(sici)10991085(199708)11:10<1427::aid-hyp473>3.0.co;2-s

The Yale Center for Earth Observation, 2013. Filling gaps in Landsat ETM images. http://www.yale.edu/ceo/Documentation/Landsat_ETM_Gap_Fill.pdf . (accessed 10.4.2016).

Tobin, G.A., Montz, B.E., 1997. Natural Hazards: Explanation and Integration. The Guilford Press, New York.

Todini, E., 1999. An operational decision support system for flood risk mapping, forecasting and management. Urban Water 1, 131-143. doi:10.1016/S14620758(00)00010-8

UNDP, 1991. Manual and guidelines for comprehensive flood loss prevenion and management. 
http://www.pacificdisaster.net/pdnadmin/data/original/JB_DM462_1991_manual_and _guidelines.pdf. (accessed 10.04.2016).

University of Texas Liberaries, 2016. India and Pakistan AMS topographic maps (1:250,000). http://www.lib.utexas.edu/maps/ams/india/ni-43-06a.jpg (accessed 23.01.2016).

USGS, 2015a. EarthExplorer web portal. http://earthexplorer.usgs.gov/ (accessed 31.12.2015).

USGS. 2015b. Landsat 8 (L8) data users handbook (version 1.0). http://www.greenpolicy360.net/mw/images/Landsat8DataUsersHandbook.pdf. (accessed 20.12.2015).

USGS LP DAAC, 2016. ASTER GDEM. http://gdex.cr.usgs.gov/gdex/ (accessed 23.01.2016).

Wang, Y., 2004. Using Landsat 7 TM data acquired days after a flood event to delineate the maximum flood extent on a coastal floodplain. Int. J. Remote Sens. 25, 959-974. doi:10.1080/0143116031000150022

Wang, Y., Colby, J.D., Mulcahy, K.A., 2002. An efficient method for mapping flood extent in a coastal floodplain using Landsat TM and DEM data.Int. J. Remote Sens. 23, 3681-3696. doi:10.1080/01431160110114484

Werner, M.G.F., 2001. Impact of grid size in GIS based flood extent mapping using a 1D flow model. Phys. Chem. Earth, Part B Hydrol. Ocean. Atmos. 26, 517-522. doi:10.1016/S1464-1909(01)00043-0

White, G.F., Kates, R.W., Burton, I., 2001. Knowing better and losing even more: The use of knowledge in hazards management. Environ. Hazards 3, 81-92. doi:10.1016/S1464-2867(01)00021-3 
Wolman, M.G., Leopold, L.B., 1957. River flood plains: some observations on their formation. U.S. Geol. Surv. Prof. Paper, 282C, 87-109.

Xu, H., 2006. Modification of normalised difference water index (NDWI) to enhance open water features in remotely sensed imagery. Int. J. Remote Sens. 27, 30253033. doi:10.1080/01431160600589179

Yang, C., Zhou, C., Wan, Q., 1999. Deciding the flood extent with Radarsat SAR data and Image Fusion. In: Proc. $20^{\text {th }}$ Asian Conference of Remote Sensing, Hong Kong, 22-25 November.

Yang, L., Meng, X., Zhang, X., 2011. SRTM DEM and its application advances. Int. J. Remote Sens. 32, 3875-3896. doi:10.1080/01431161003786016

Zhang, F., Tiyip, T., Kung, H., Johnson, V.C.,Wang, J., Nurmemet, I., 2016. Improved water extraction using Landsat TM/ETM+ images in Ebinur Lake, Xinjiang, China. Remote Sens. Appl. Soc. Environ. 4, 109-118. doi:10.1016/j.rsase.2016.08.001 


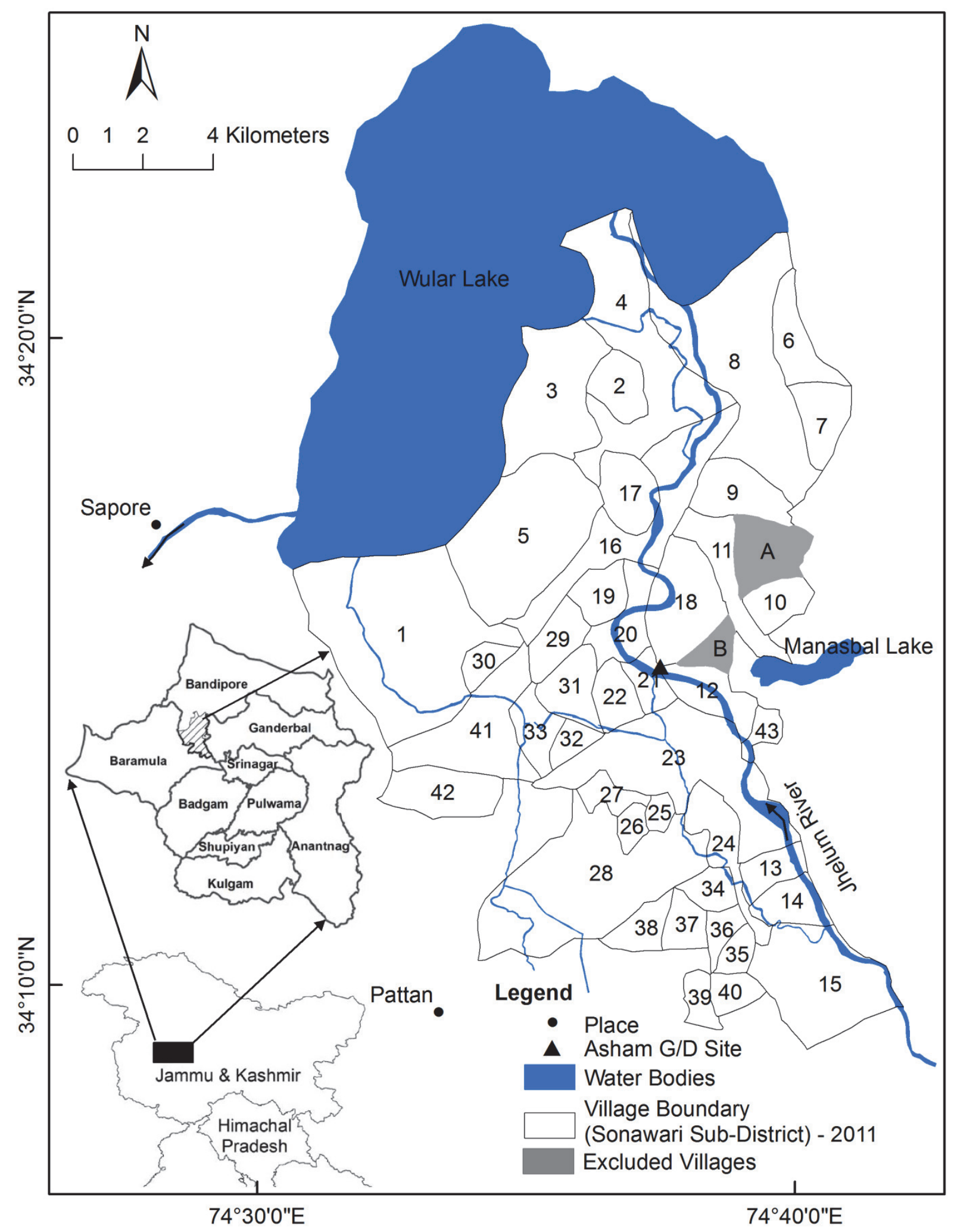

Fig.1. Location map of the study area. 


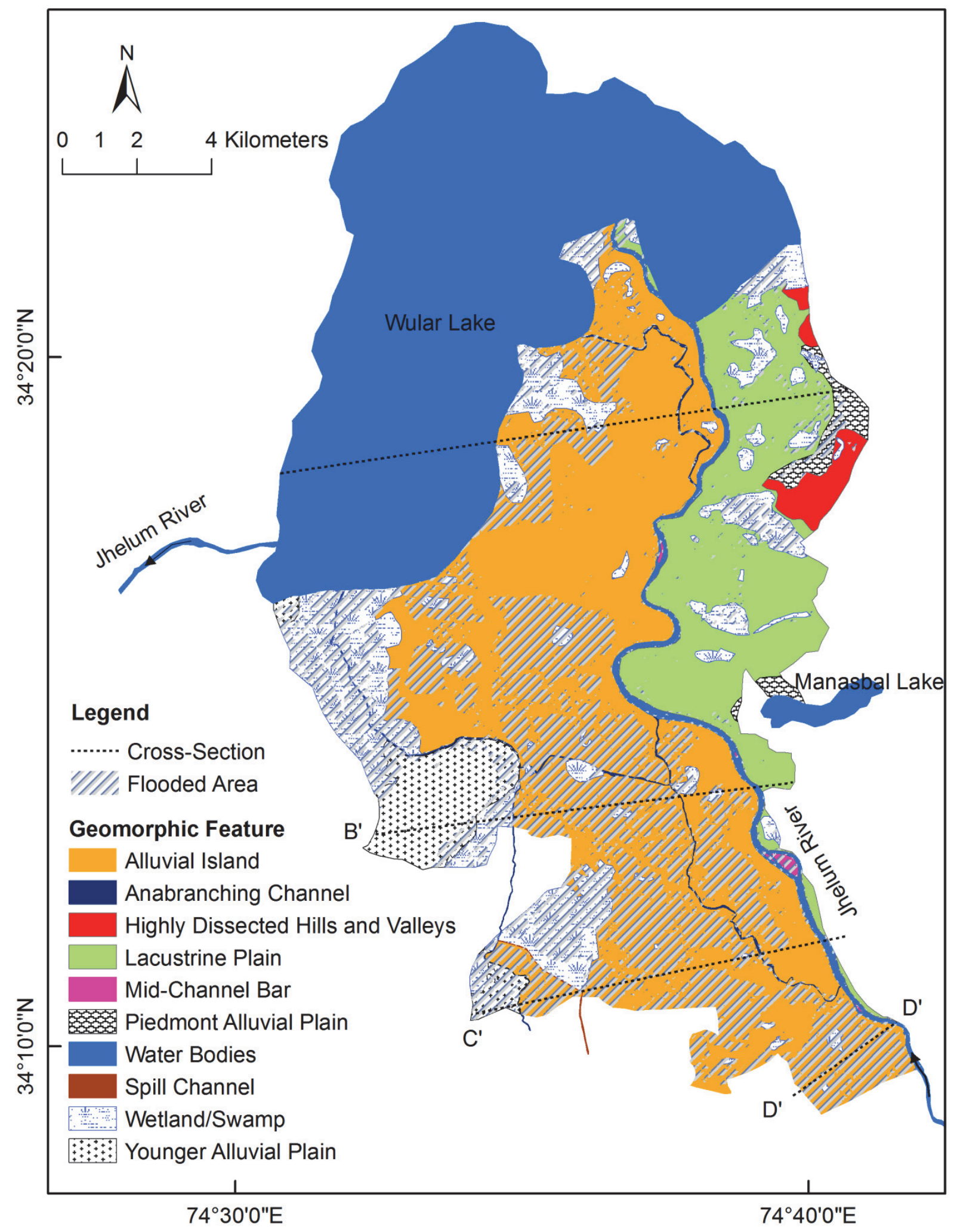

Fig.2. Geomorphology of the study area (Modified after GSI and NRSC, 2005-06). 


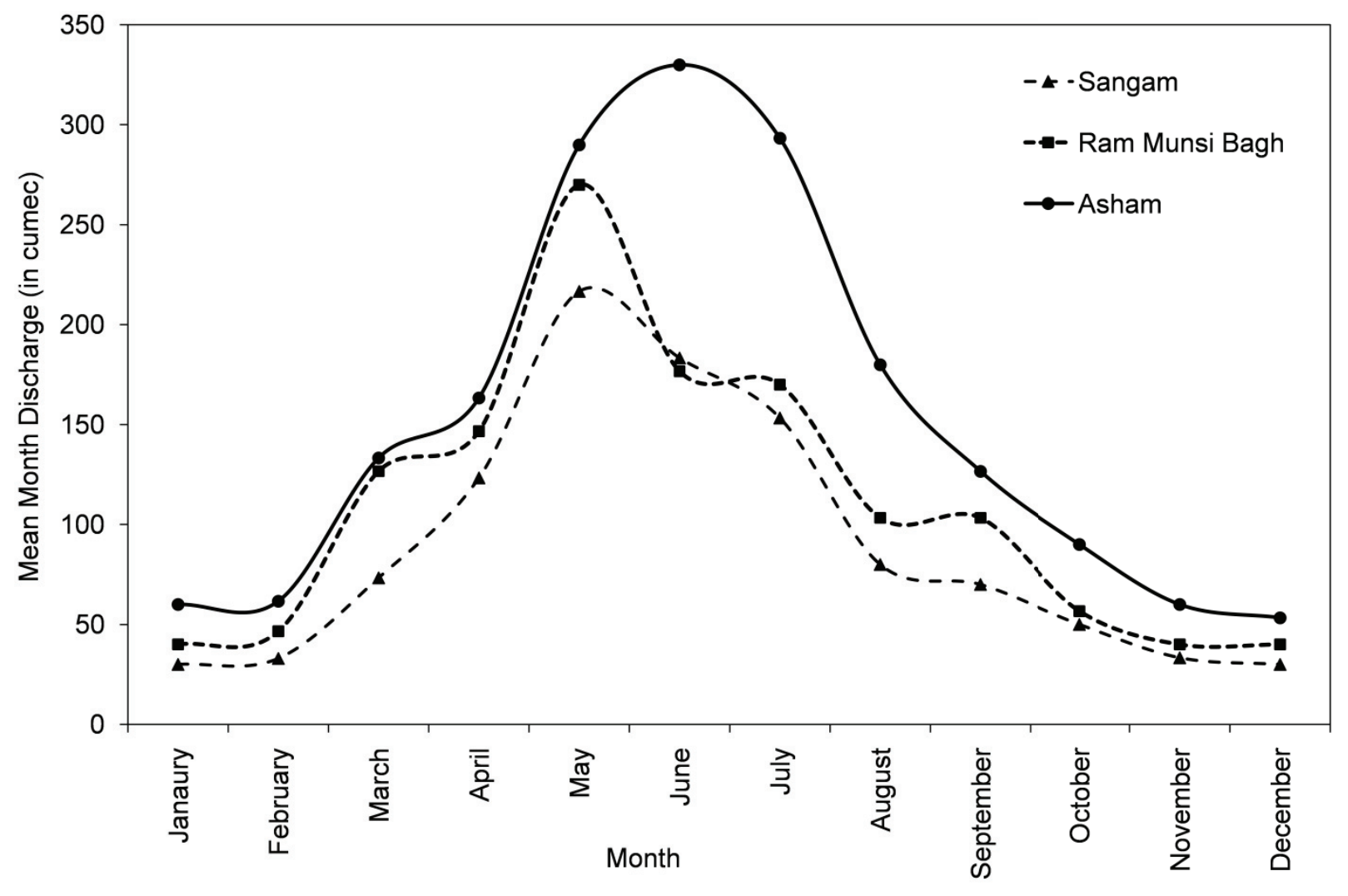

Fig. 3. Mean monthly discharge in Jhelum River (2003-2012) (modified after Showkat et al., 2014). 
$\mathrm{VE}=120$

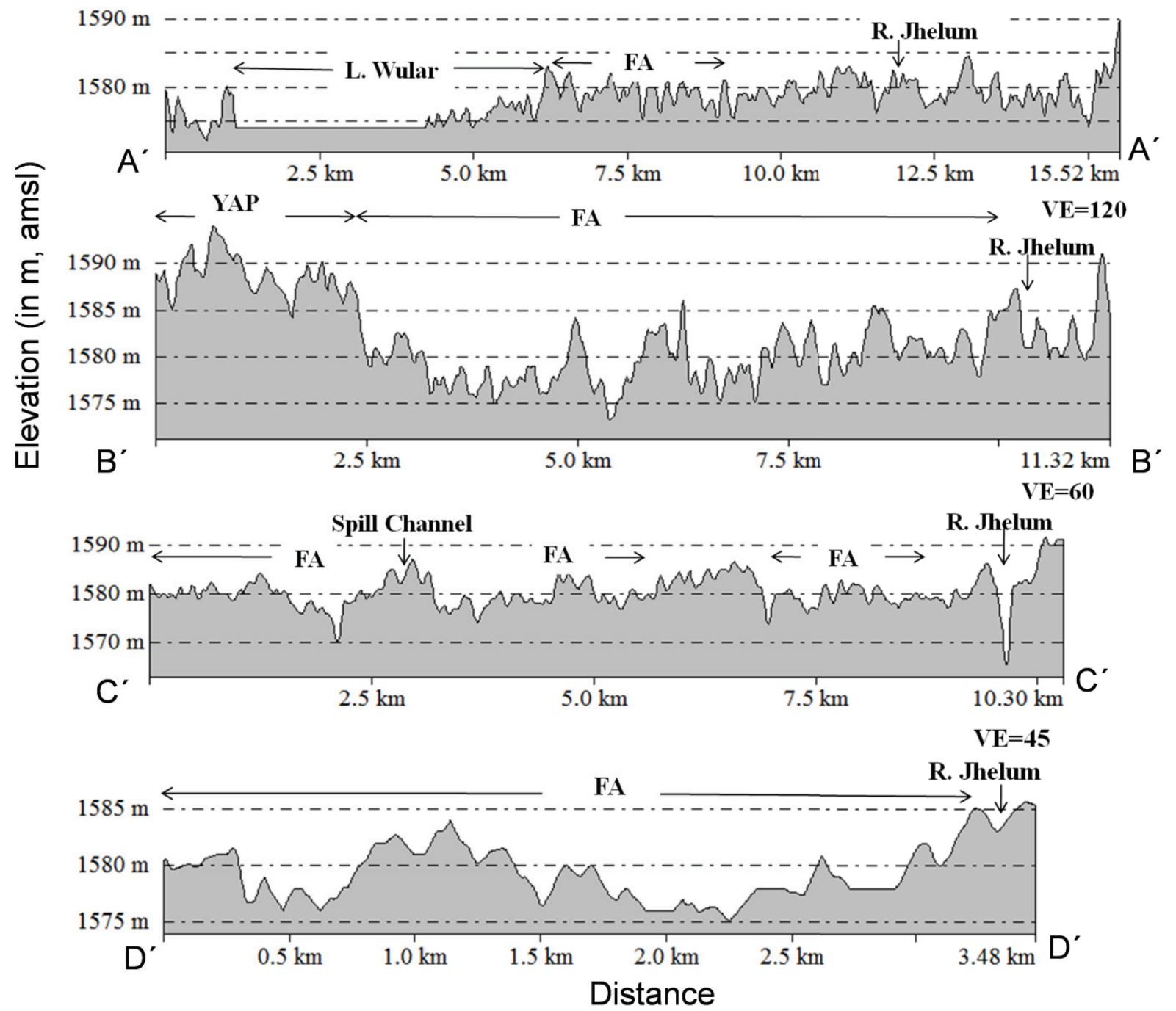

Fig. 4. Cross profile between specified points. Horizontal arrows show flooded areas (FA). 


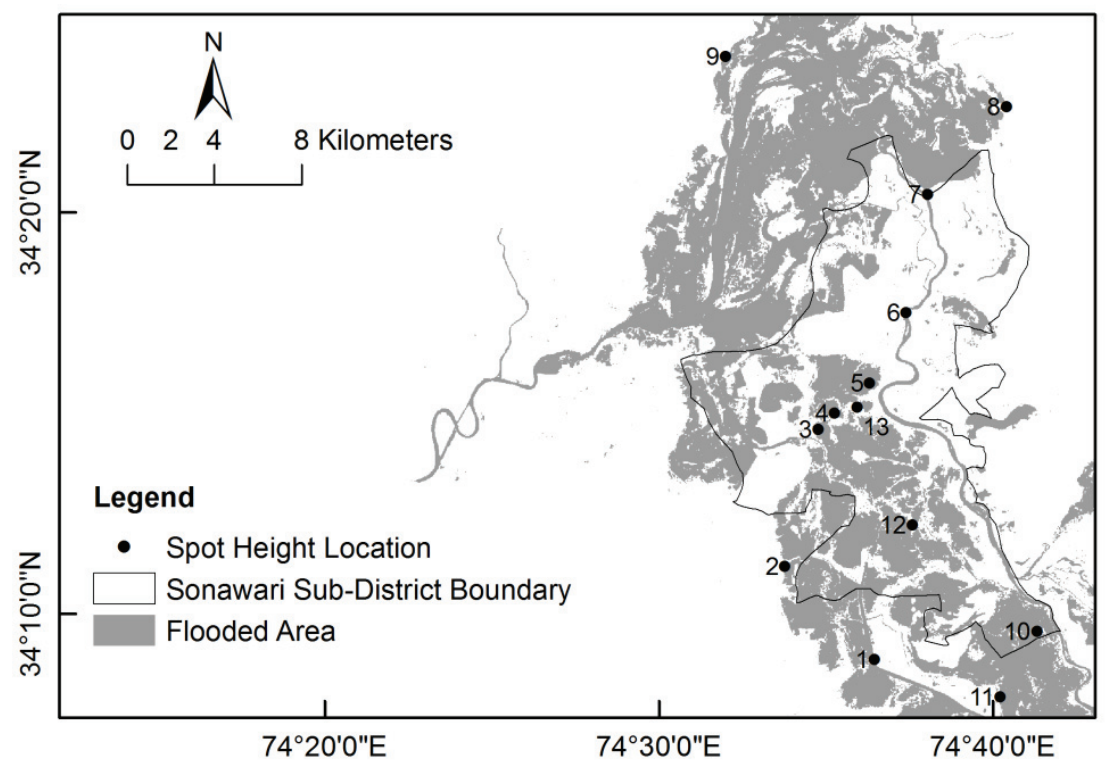

Fig.5. Planform map of spot height.

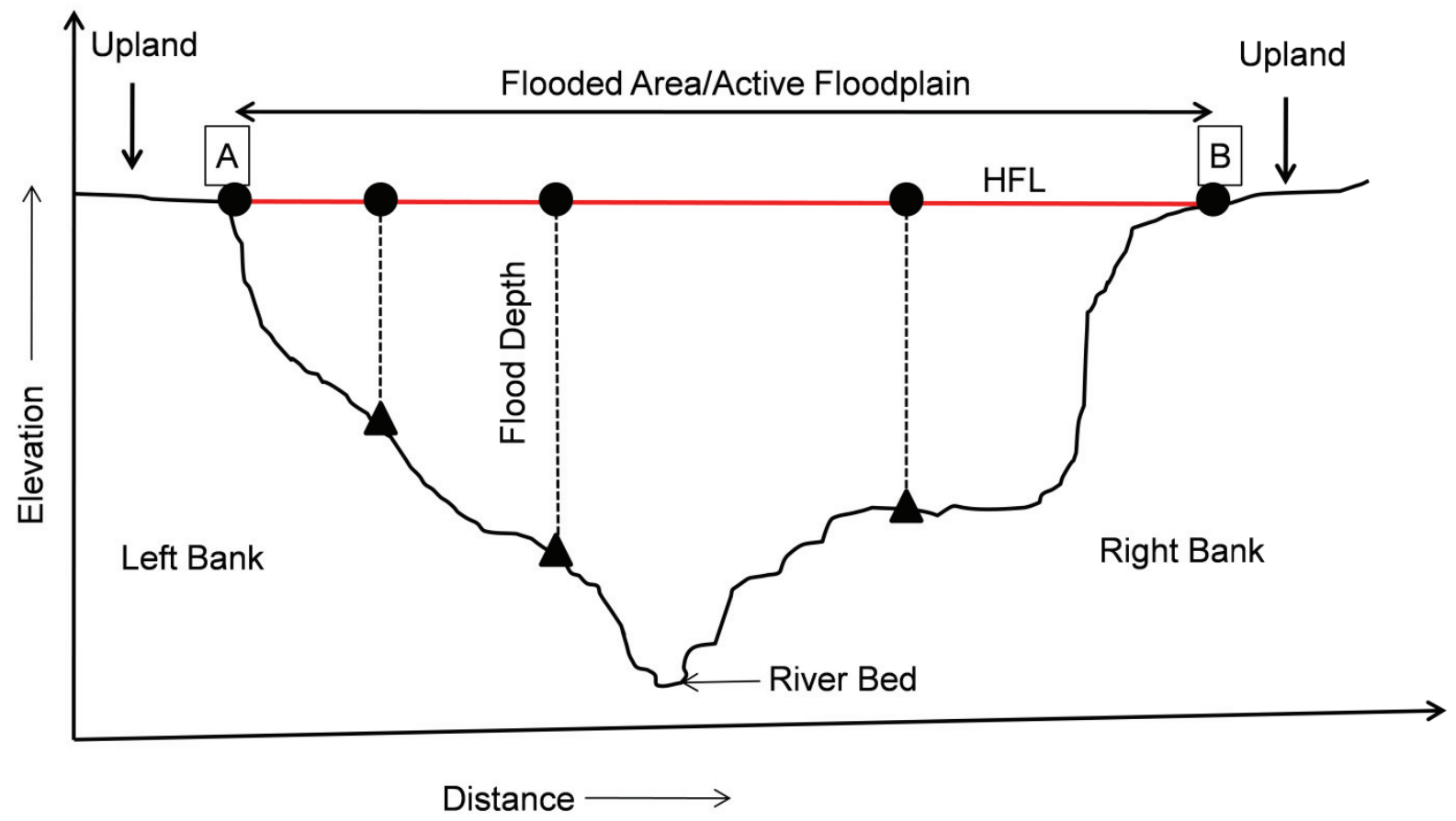

Fig.6. Schematic diagram of flood depth estimation. Black circles between A and B show the maximum water level or highest flood level in the flooded area/active 
floodplain. Black triangles denote ground elevation. The vertical dotted lines represent flood depth above ground level.

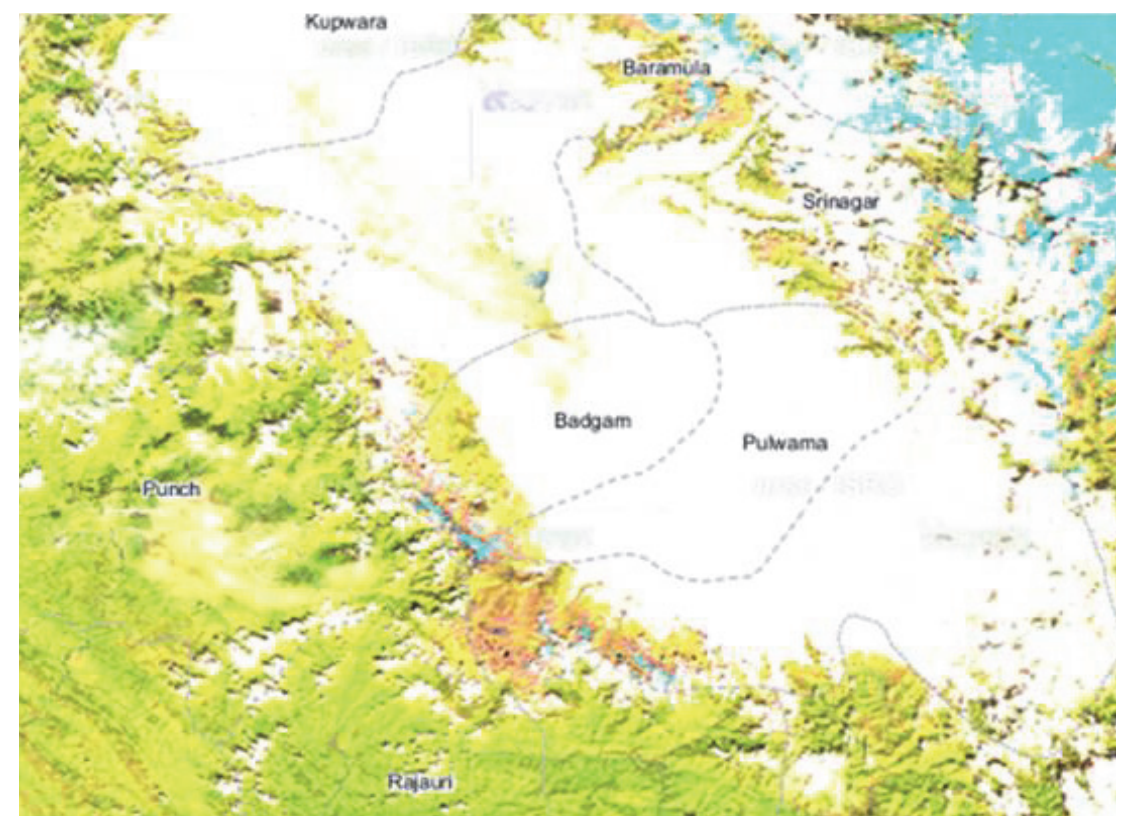

Fig.7. Cloud cover over Kashmir valley (07.09.2014). 

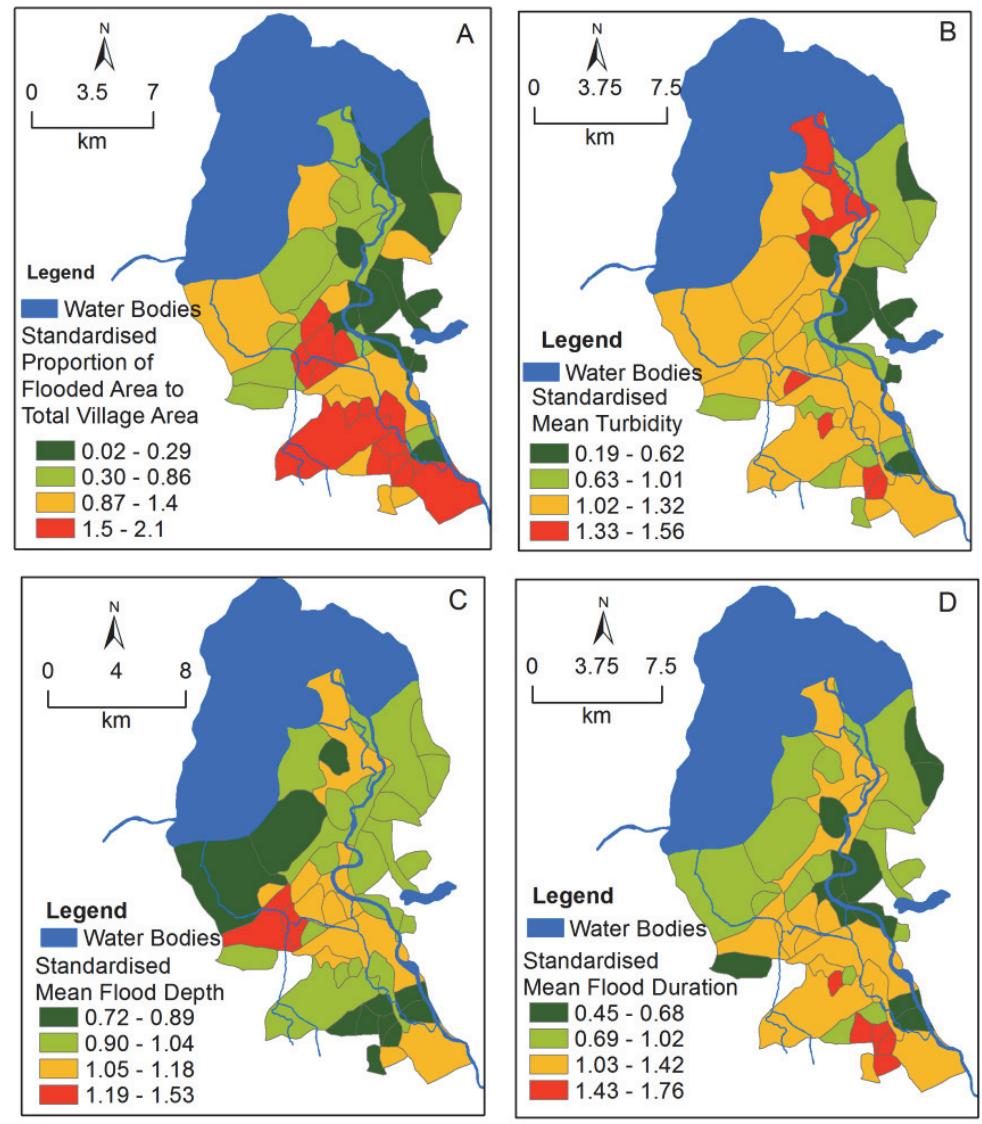

Fig.8. Standardised indicators (A-D) used in flood hazard index computation in Sonawari sub-district. 


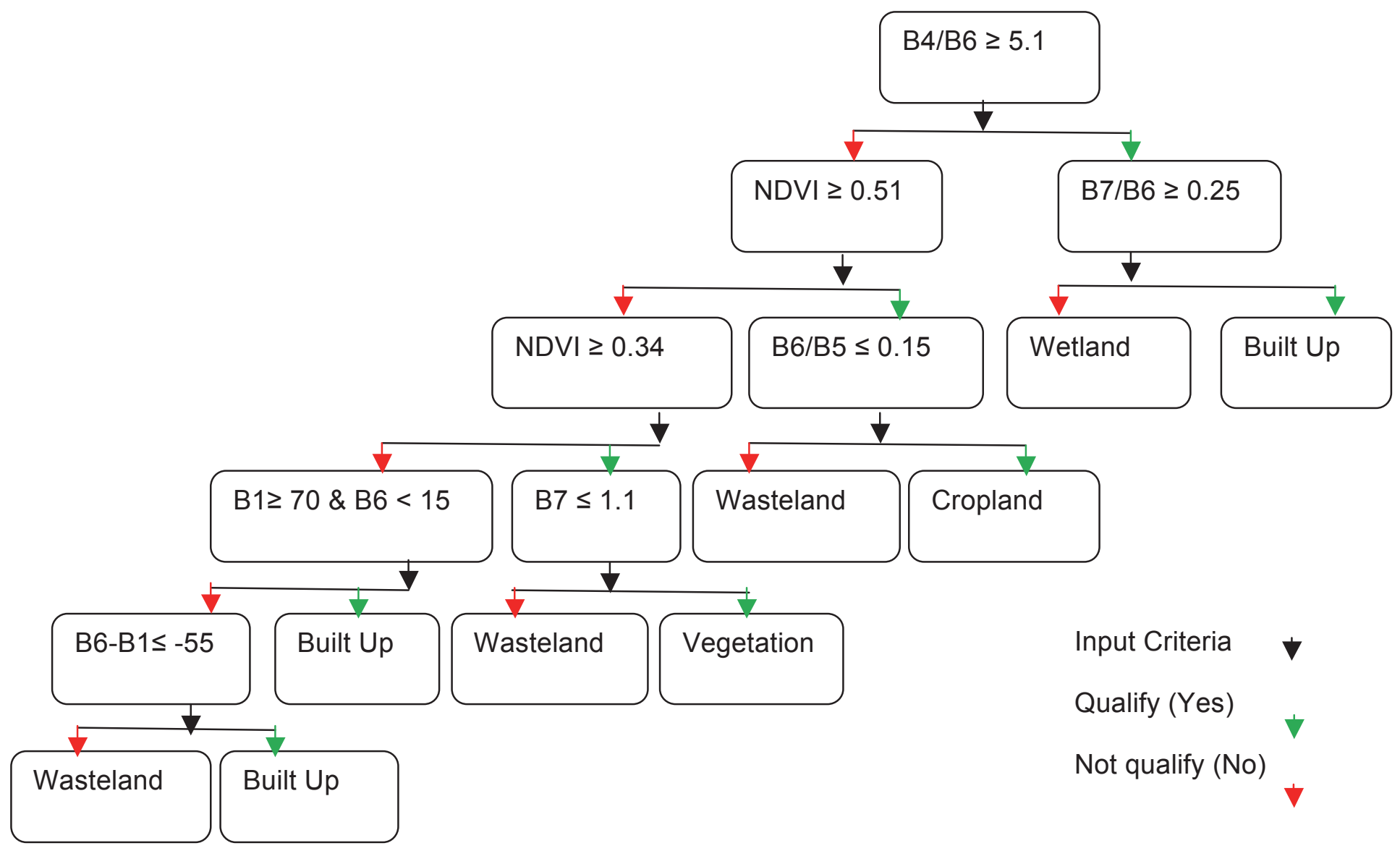

Fig. 9. Land use and land cover classification using decision tree criteria. 


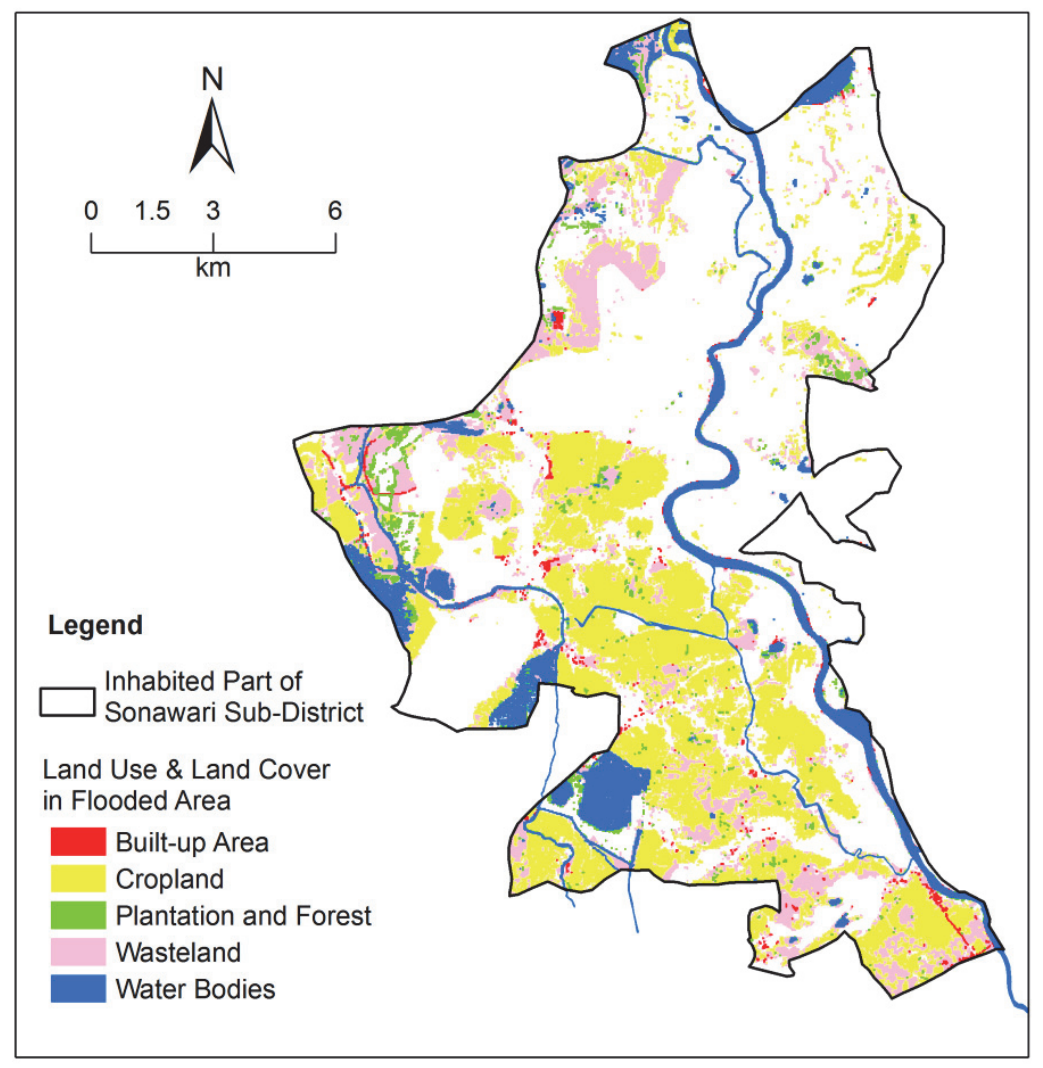

Fig. 10. Land use and land cover in flooded areas. 


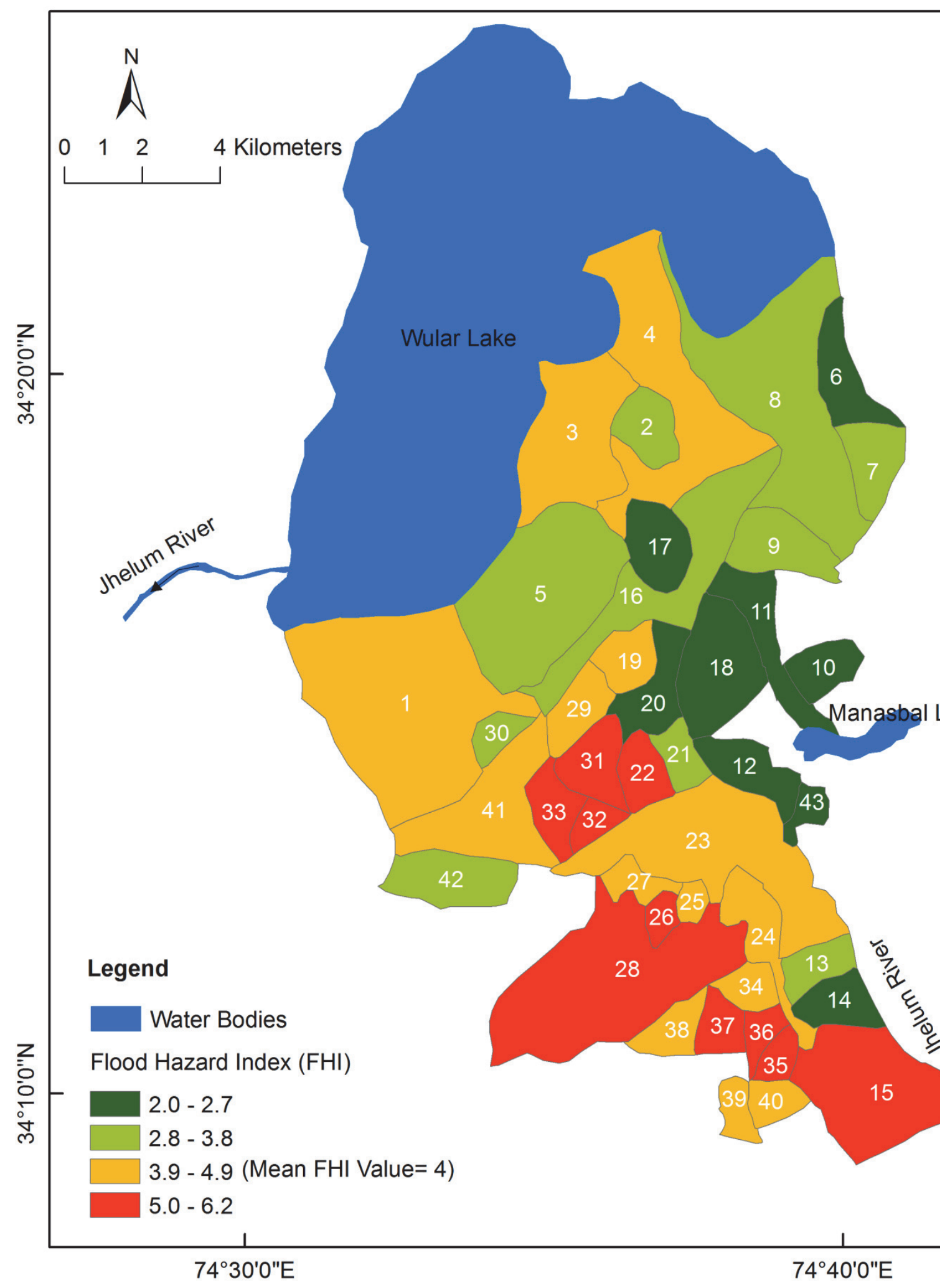

Fig. 11. Flood hazard map of the study area. 


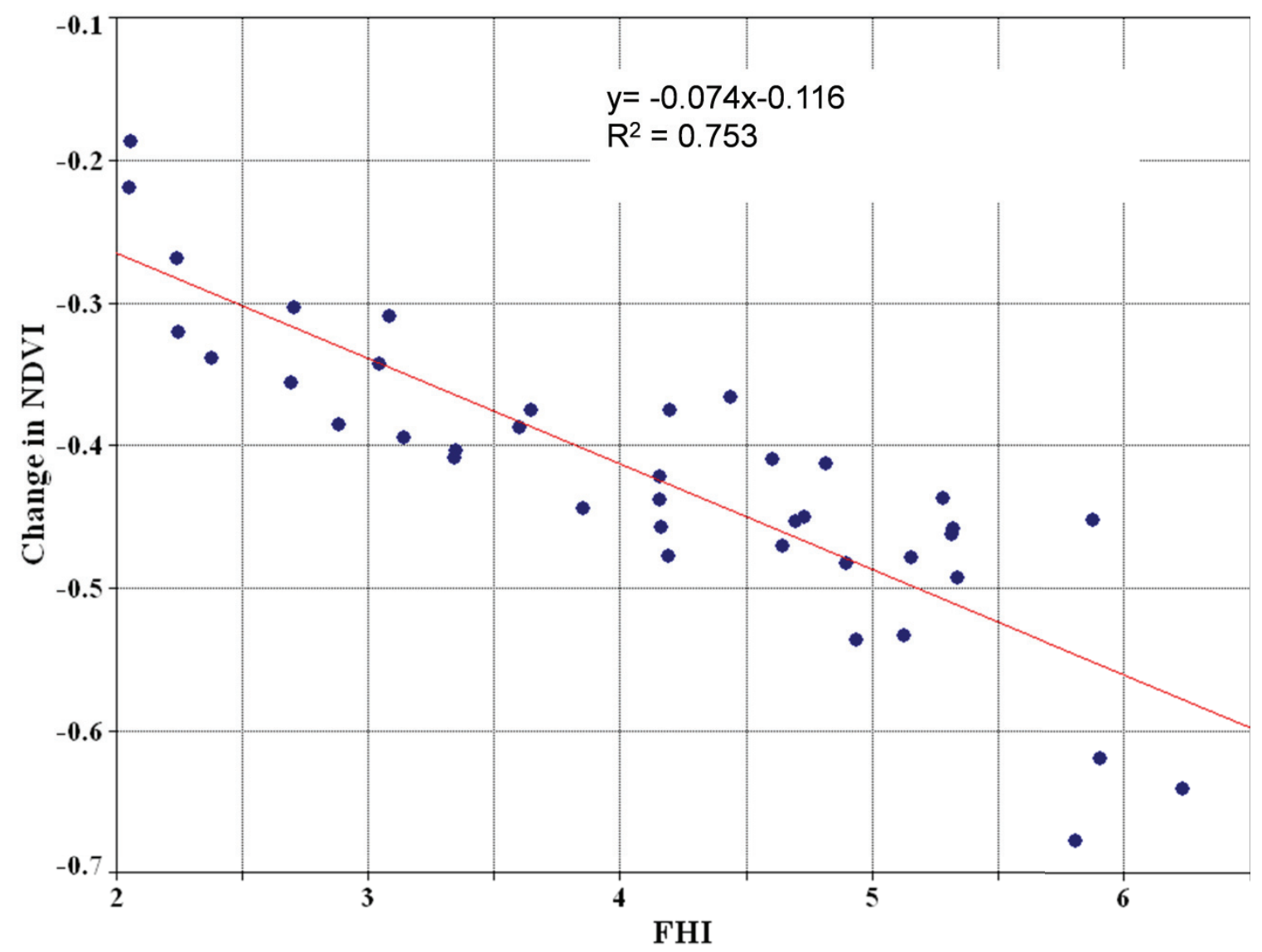

Fig. 12. Association between FHI values and changes in NDVI values. 


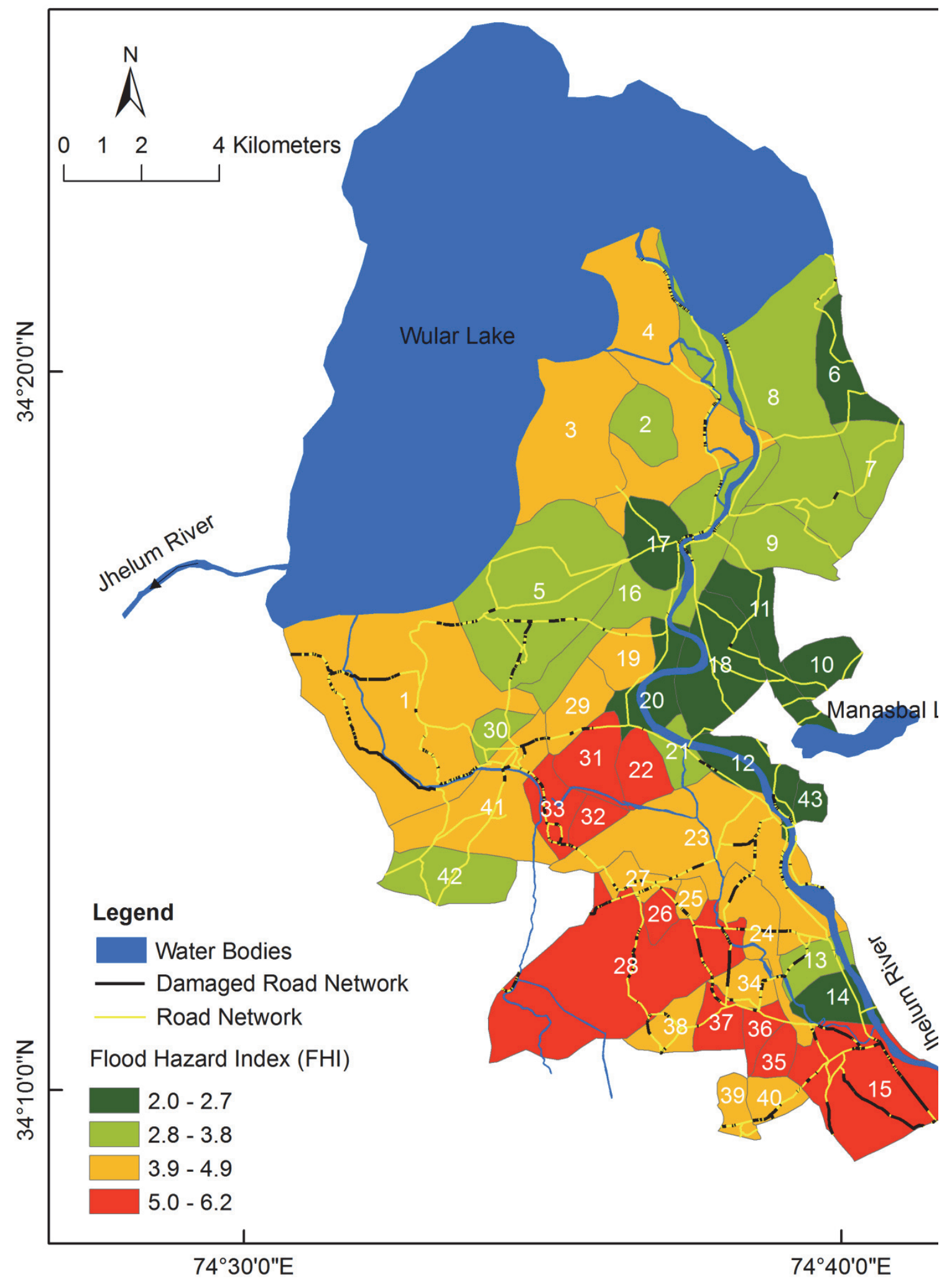


Fig.13. Damaged portions of road network.

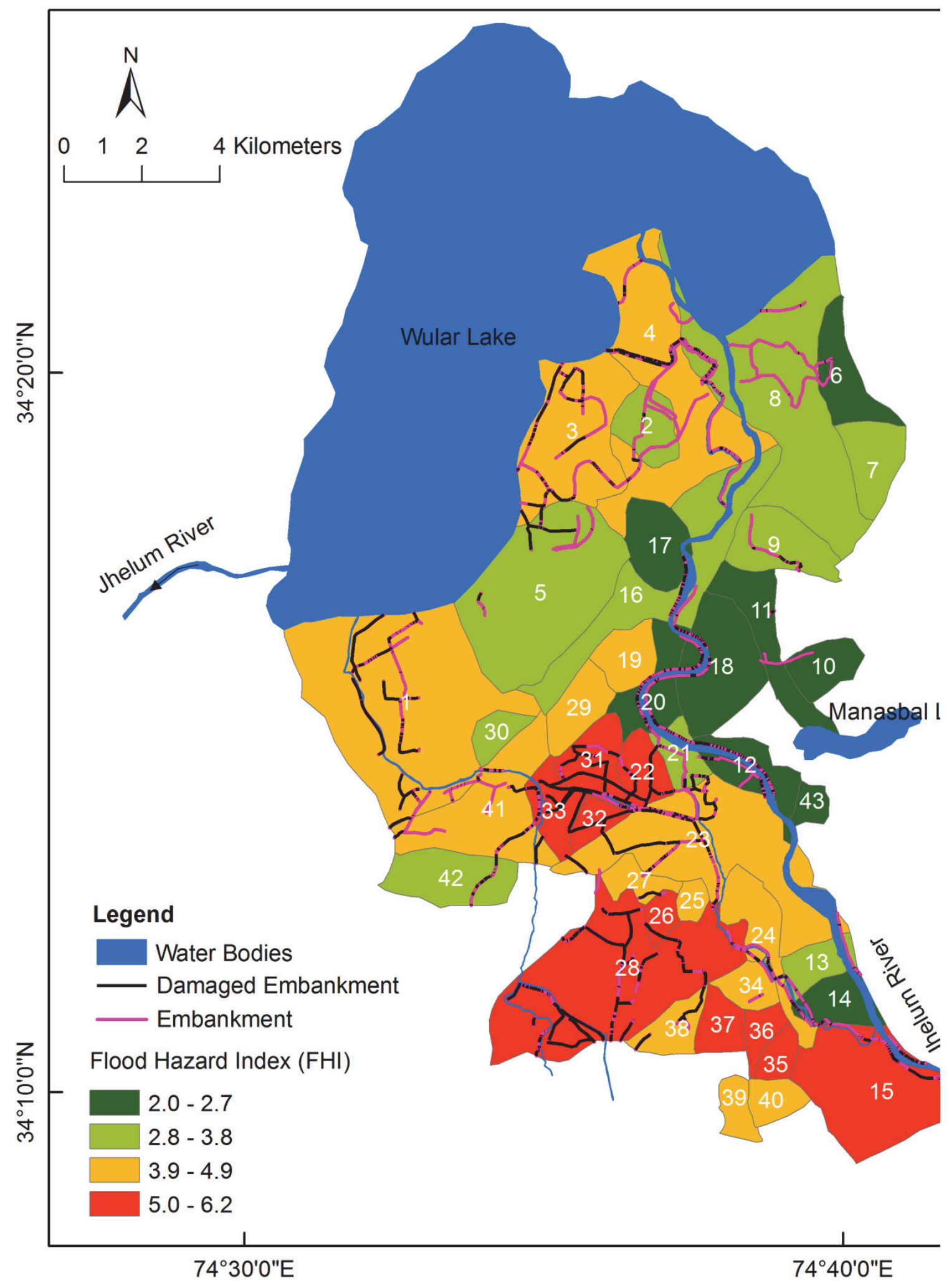


Fig. 14. Damaged portions of embankments. 


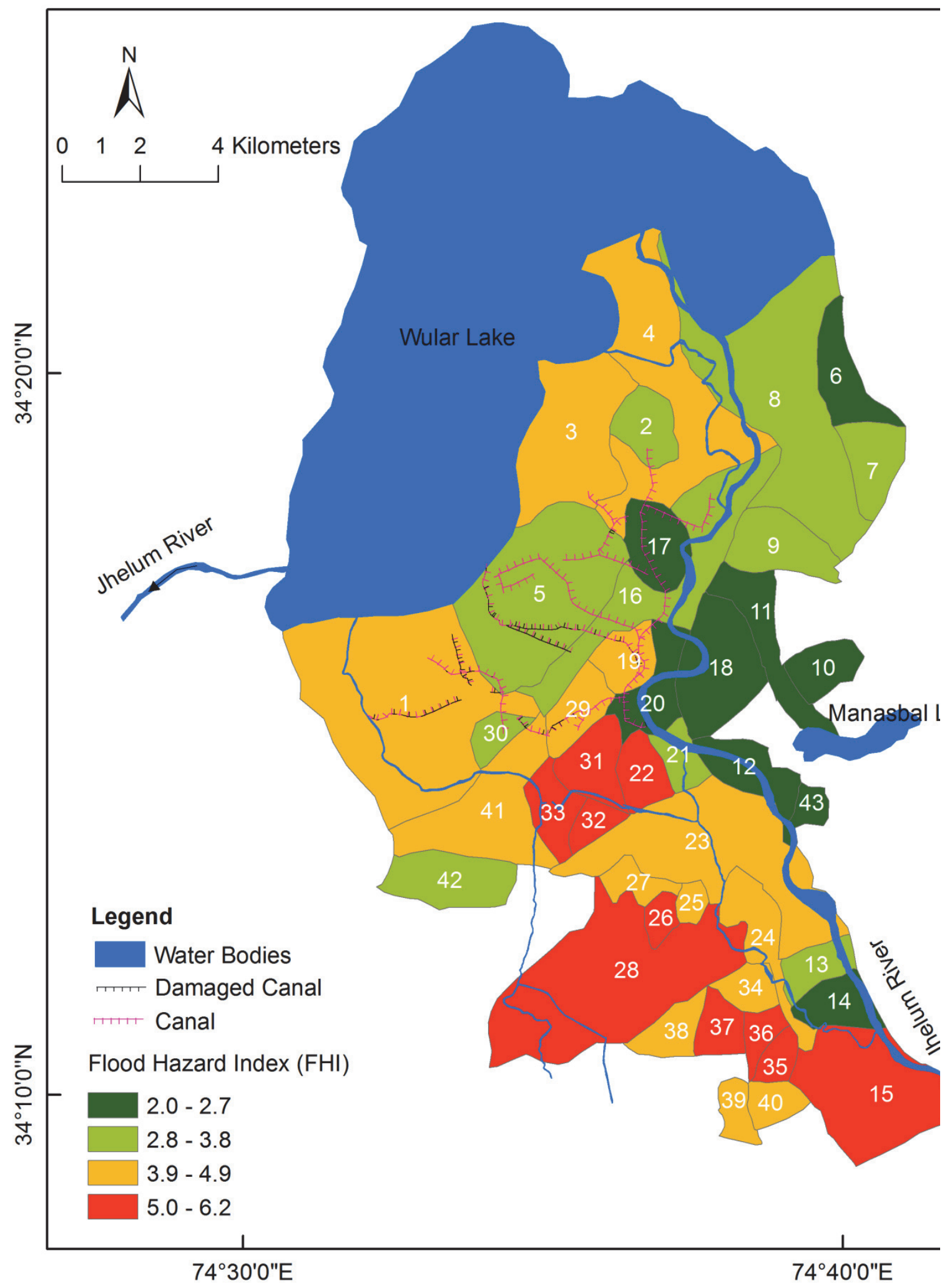

Fig. 15. Damaged portions of Canals. 

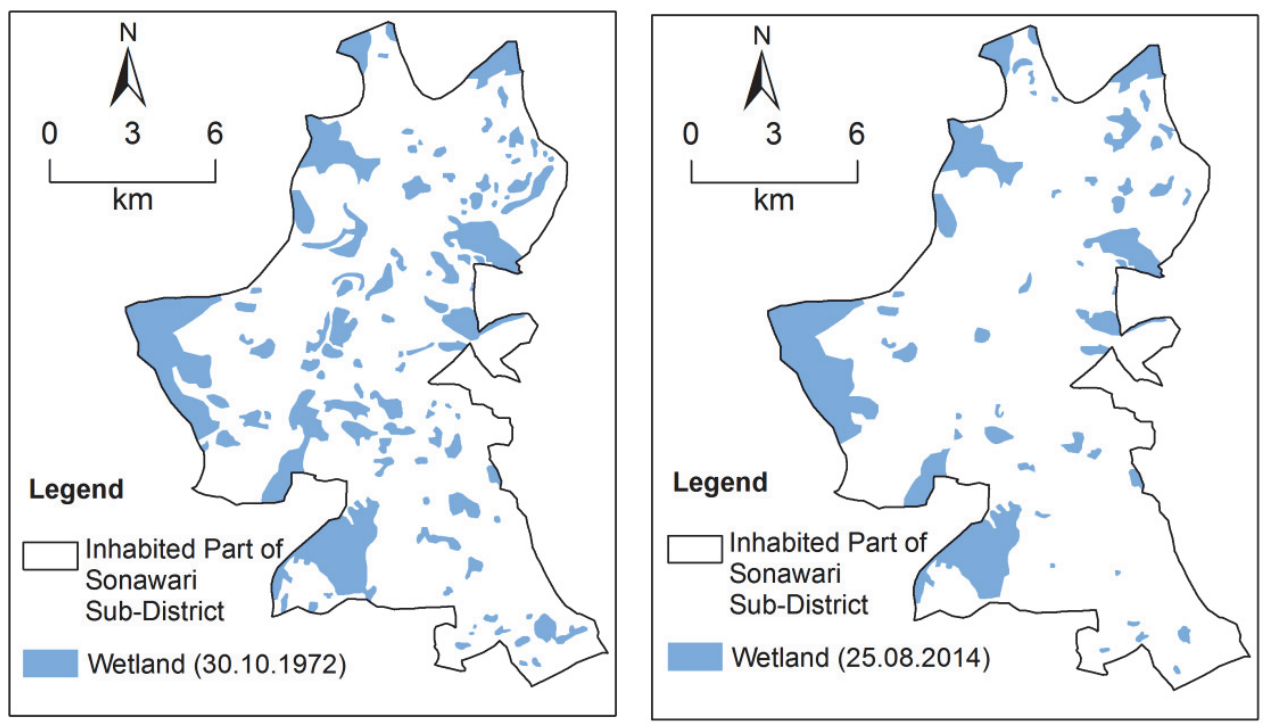

Fig. 16. Change in wetlands and swamps (1972-2014).

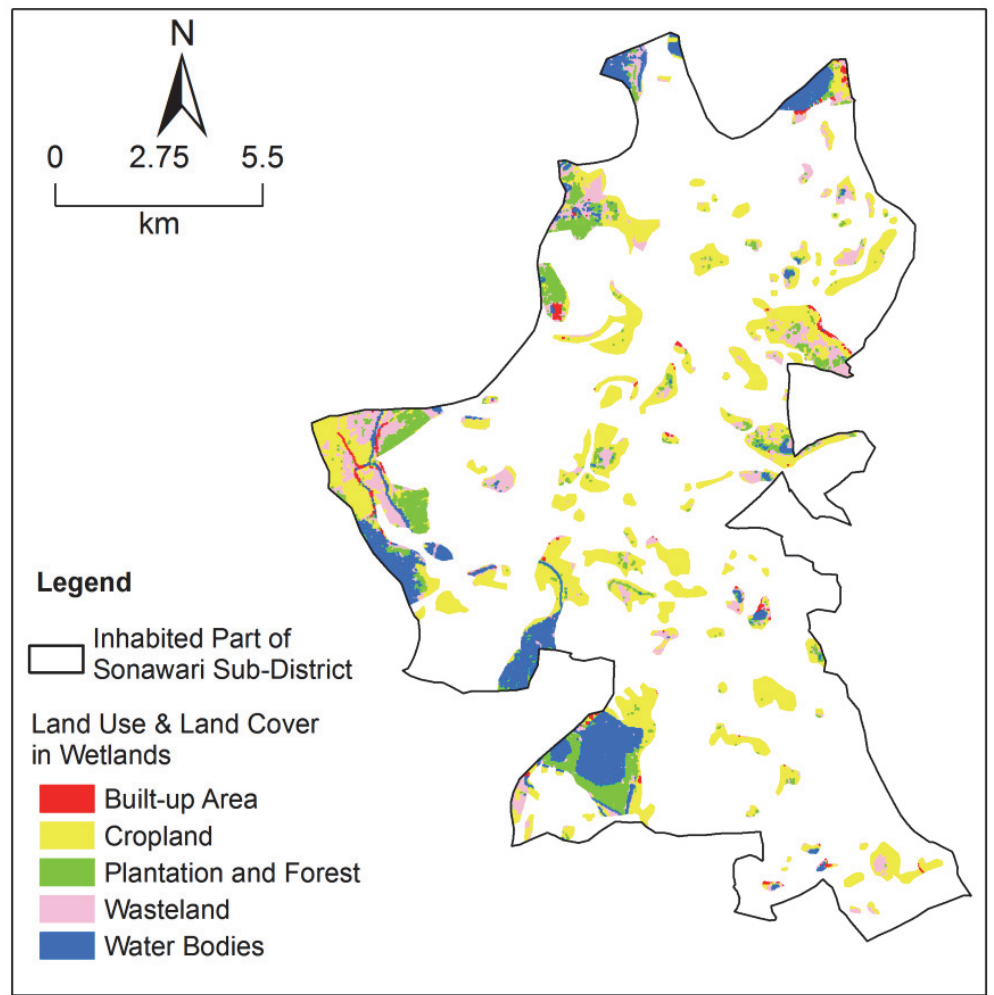

Fig.17. Recent land use and land cover in wetlands and swamps of 1972. 
Table 1 List of villages and towns in Sonawari sub-district.

\begin{tabular}{llll}
\hline $\begin{array}{l}\text { Label } \\
\text { ID }\end{array}$ & Village/Town Name & Label ID & $\begin{array}{l}\text { Village/Town } \\
\text { Name }\end{array}$ \\
\hline 1 & Gundi Jahangir & 23 & Sumbal (NAC) \\
2 & Madwan & 24 & Rakh Shilvat \\
3 & Siri Hari Karan Gund & 25 & Gund Nowgam \\
4 & Gund Prang & 26 & Nowgam \\
5 & Shah Gund & 27 & Zal Pora \\
6 & Sadrakote Pain & 28 & Rakh Sultan Pora \\
7 & Ajas & 29 & Gund Bun \\
8 & Sadhunara Hasti Khan & 30 & Gundi Balakh \\
9 & Gund Sadra Kote & 31 & Push Wari \\
10 & Chiva & 32 & Tanga Pora \\
11 & Chander Gair & 33 & Kani Pora \\
12 & Asham & 34 & Ganstan \\
13 & Shilvat & 35 & Tirgam \\
14 & Shadi Pora & 36 & Gund Khalil \\
15 & Sarai Danger Pora & 37 & Najin \\
16 & Hajan (MC) & 38 & Gada Khud \\
17 & Rakh Hajin & 39 & Odina \\
18 & Kosum Bagh (Hakbara) & 40 & Malik Pora \\
19 & Vij Pora & 41 & Sadat Pora( Naid \\
& & & Khai) \\
20 & Bahar Abad (Amcha & 42 & Watal Hanji \\
21 & Kundal) & & \\
22 & Gulshan Pora( & 43 & Hilal Abad (Nisbal) \\
22 & Garkundal) & & \\
\hline
\end{tabular}


Table 2 Weekly rainfall departure from normal (in per cent).

\begin{tabular}{lccccc}
\hline $\begin{array}{l}\text { Week Ending } \\
\text { on }\end{array}$ & Anantnag & Pulwama & Badgam & Srinagar & Baramula \\
\hline 13.08 .14 & -48.0 & -96.0 & -100.0 & -100.0 & -95.0 \\
20.08 .14 & 525.0 & 346.0 & 271.0 & 295.0 & 196.0 \\
27.08 .14 & 0.0 & -60.0 & -71.0 & -17.0 & -62.0 \\
03.09 .14 & 451.0 & 282.0 & 209.0 & 378.0 & 61.0 \\
10.09 .14 & 168.0 & 1711 & 293.0 & 1410.0 & 1489.0 \\
17.09 .14 & -71.0 & -64.0 & -100.0 & 93.0 & -100.0 \\
24.09 .14 & -100 & -100 & -100 & -100 & -100 \\
1.10 .14 & 13 & -3 & 12 & -16 & -20 \\
8.10 .14 & 333 & 427 & 307 & 245 & 66 \\
15.10 .14 & -92.0 & -91.0 & -86.0 & -36.0 & -7.0 \\
\hline
\end{tabular}

Source: National Agrometeorological Advisory Service Centre, Agricultural Meteorology Division, India Meteorological Department (IMD), Pune.

Table 3 Description of satellite images.

\begin{tabular}{lccccc}
\hline Sensor & $\begin{array}{c}\text { Date of } \\
\text { Acquisition }\end{array}$ & Path/Row & $\begin{array}{c}\text { Scan Time } \\
(\mathrm{GMT})\end{array}$ & $\begin{array}{c}\text { Sun } \\
\text { Azimuth } \\
(\mathrm{deg})\end{array}$ & $\begin{array}{c}\text { Sun } \\
\text { Elevation } \\
\text { (deg) }\end{array}$ \\
\hline Landsat8 OLI- & $25 / 08 / 2014$ & $149 / 36$ & $05: 35: 52.6938$ & 134.82938 & 59.1294365 \\
TIRS & & & 503 & 46 & 9 \\
Landsat8 OLI- & $10 / 9 / 2014$ & ditto & $05: 35: 56.6638$ & 142.66527 & 54.9612541 \\
TIRS & & & 951 & 39 & 9 \\
Landsat7 ETM+ & $18 / 09 / 2014$ & ditto & $05: 33: 29.8248$ & 145.47850 & 52.1924142 \\
& & & 143 & 37 & \\
Landsat8 OLI- & $26 / 09 / 2014$ & ditto & $05: 35: 53.5759$ & 149.42524 & 50.1301016 \\
TIRS & & & 716 & 53 & 1 \\
Landsat7 ETM+ & $04 / 10 / 2014$ & ditto & $05: 33: 42.0906$ & 151.56074 & 47.1795530 \\
& & & 363 & 7 & 3 \\
Landsat8 OLI- & $12 / 10 / 2014$ & Ditto & $05: 36: 00.8835$ & 154.62744 & 44.9300820 \\
TIRS & & & 676 & 1 & 5 \\
Lansat1 MSS & $30 / 10 / 1972$ & $160 / 36$ & $05: 06: 54.100$ & 150 & 36 \\
\hline
\end{tabular}




\begin{tabular}{|c|c|c|c|c|}
\hline Class & Commission (\%) & $\begin{array}{l}\text { Omission } \\
(\%)\end{array}$ & $\begin{array}{l}\text { Commission } \\
\text { (Pixels) }\end{array}$ & $\begin{array}{l}\text { Omission } \\
\text { (Pixels) }\end{array}$ \\
\hline Flooded & 6.67 & 17.65 & $1 / 15$ & $3 / 17$ \\
\hline \multirow{3}{*}{$\begin{array}{l}\text { Non- } \\
\text { Flooded }\end{array}$} & 18.75 & 7.14 & $3 / 16$ & $1 / 14$ \\
\hline & Producer & User & Producer & User \\
\hline & $\begin{array}{c}\text { Accuracy } \\
(\%)\end{array}$ & $\begin{array}{c}\text { Accuracy } \\
(\%)\end{array}$ & $\begin{array}{l}\text { Accuracy } \\
\text { (Pixels) }\end{array}$ & $\begin{array}{l}\text { Accuracy } \\
\text { (Pixels) }\end{array}$ \\
\hline Flooded & 82.35 & 93.33 & $14 / 17$ & $14 / 15$ \\
\hline $\begin{array}{l}\text { Non- } \\
\text { Flooded }\end{array}$ & 92.86 & 81.25 & $13 / 14$ & $13 / 16$ \\
\hline
\end{tabular}

Table 4 Accuracy assessment of flooded and non-flooded areas (September 10, 2014).

Overall accuracy $=87.09$ per cent; Kappa coefficient $=0.74$

Table 5 Weightage values for each flood inundation layer.

\begin{tabular}{llcc}
\hline S. No. & Date of Inundation Layer & Duration of Staying $(\mathrm{t})$ & Weight $(\mathrm{W})$ \\
\hline 1 & 07.09 .2014 & 0 & 0 \\
2 & 10.09 .2014 & 3 & 0.08 \\
3 & 18.09 .2014 & 8 & 0.23 \\
4 & 26.09 .2014 & 8 & 0.23 \\
5 & 04.10 .2014 & 8 & 0.23 \\
6 & 12.10 .2014 & 8 & 0.23 \\
& Total $(\mathrm{m})$ & 35 & 1.0 \\
\hline
\end{tabular}

Table 6 Accuracy assessment of different LU/LC classes (August 25, 2014).

\begin{tabular}{lcc}
\hline LU/LC Class & $\begin{array}{c}\text { Producer Accuracy (in } \\
\text { per cent) }\end{array}$ & $\begin{array}{c}\text { User } \\
\text { Accuracy (in per } \\
\text { cent) }\end{array}$ \\
\hline Built-up & 66.67 & 83.33 \\
Plantation/Forest & 72.22 & 86.67 \\
Water bodies & 94.44 & 94.44 \\
Waste land & 86.36 & 76.00 \\
Cropped area & 87.50 & 87.50 \\
\hline
\end{tabular}


Overall accuracy $=82.47$ per cent; Kappa coefficient $=0.78$

Table 7 Change in MNDWI values in Inundated part of Sonawari sub-district.

\begin{tabular}{ccccccc}
\hline Date & Min. & Max & Mean & SD & $\begin{array}{c}\text { Flooded Area } \\
(\text { sq.km })\end{array}$ & $\begin{array}{c}\text { Actual Flooded Area } \\
(\text { sq. km) }\end{array}$ \\
\hline $25 / 08 / 2014$ & 0 & 0.81 & 0.47 & 0.25 & 12 & 0 \\
$10 / 9 / 2014$ & 0 & 0.96 & 0.64 & 0.31 & 57 & 45 \\
$18 / 09 / 2014$ & 0 & 0.97 & 0.56 & 0.29 & 79 & 67 \\
$26 / 09 / 2014$ & 0 & 0.94 & 0.50 & 0.27 & 55 & 42 \\
$4 / 10 / 2014$ & 0 & 0.84 & 0.31 & 0.20 & 40 & 28 \\
$12 / 10 / 2014$ & 0 & 0.89 & 0.38 & 0.22 & 25 & 13 \\
\hline
\end{tabular}

Table 8 Flood Depth (in metre) in Sonawari sub-district.

\begin{tabular}{ccccc}
\hline Date & Min. & Max. & Mean & SD \\
\hline 10 \& 18 Sept. 2014 & 0.5 & 8.5 & 2.81 & 0.88 \\
\hline
\end{tabular}

Table 9 Land use/land cover in the flooded areas (August 25, 2014).

\begin{tabular}{lcc}
\hline Lu/LC & $\begin{array}{c}\text { Area } \\
\left(\mathrm{Km}^{2}\right)\end{array}$ & $\begin{array}{c}\text { Area in Per } \\
\text { cent }\end{array}$ \\
\hline Built-up & 1.12 & 1 \\
Plantation/Forest & 2.79 & 3 \\
Water bodies & 12.41 & 14 \\
Waste land & 25.49 & 29 \\
Cropped area & 46.26 & 53 \\
Total & 88.07 & 100 \\
\hline
\end{tabular}

Table 10 Overall NDVI Change in inundated part of Sonawari Sub-District during pre and post flood.

\begin{tabular}{ccccc}
\hline Date & Min. & Max. & Mean & SD \\
\hline $25 / 08 / 2014$ & -0.94 & 0.88 & 0.72 & 0.10 \\
$12 / 10 / 2014$ & -0.56 & 0.80 & 0.29 & 0.20 \\
\hline
\end{tabular}


Table 11 NDVI change in inundated crop land of Sonawari sub-district during pre and post flood.

\begin{tabular}{ccccc}
\hline Date & Min. & Max. & Mean & SD \\
\hline $25 / 08 / 2014$ & 0.69 & 0.88 & 0.78 & 0.03 \\
$12 / 10 / 2014$ & -0.42 & 0.80 & 0.29 & 0.19 \\
\hline
\end{tabular}

Table 12 NDVI change in inundated forest and plantation area of Sonawari sub-district during pre and post flood.

\begin{tabular}{ccccc}
\hline Date & Min. & Max. & Mean & SD \\
\hline $25 / 08 / 2014$ & 0.54 & 0.78 & 0.68 & 0.04 \\
$12 / 10 / 2014$ & -0.53 & 0.76 & 0.41 & 0.20 \\
\hline
\end{tabular}


Table 13 Areal extent, total population, population density, no. of villages and towns under different flood hazard classes. 
*Area of Malgam and Zani Pora villages is not included.

\begin{tabular}{|c|c|c|c|c|c|}
\hline FHI Class & $\begin{array}{l}\text { Area } \\
\left(\mathrm{Km}^{2}\right)\end{array}$ & $\begin{array}{c}\text { Total } \\
\text { Population } \\
(2011)\end{array}$ & $\begin{array}{c}\text { Population } \\
\text { Density } \\
\text { (2011) }\end{array}$ & $\begin{array}{c}\text { No. of } \\
\text { Villages }\end{array}$ & Village with Label Id \\
\hline $\begin{array}{l}2.0-2.7 \\
\text { (Low) }\end{array}$ & 30 & 33777 & 1126 & 09 & $\begin{array}{l}\text { Sadrakote Pain (6), Chiva (10), } \\
\text { Chander Gair (11), Asham (12), } \\
\text { Shadi Pora (14), Rakh Hajin } \\
\text { (17), Kosum Bagh } \\
\text { (Hakbara)(18), Bahar Abad } \\
\text { (Amcha Kundal) (20) and Hilal } \\
\text { Abad (Nisbal) (43), }\end{array}$ \\
\hline $\begin{array}{l}2.8-3.8 \\
\text { (Moderate) }\end{array}$ & 57 & 57573 & 1010 & 10 & $\begin{array}{l}\text { Madwan (2), Shah Gund (5), } \\
\text { Ajas (7),Sadhunara Hasti Khan } \\
\text { (8),Gund Sadra Kote (9), Shilvat } \\
\text { (13), Hajin (MC)(16), Gulshan } \\
\text { Pora( Markundal) (21), Gundi } \\
\text { Balakh (30) and Watal Hanji } \\
\text { (42) }\end{array}$ \\
\hline $\begin{array}{l}3.9-4.9 \\
\text { (High) }\end{array}$ & 60 & 55772 & 930 & 14 & $\begin{array}{l}\text { Gundi Jahangir (1), Siri Hari } \\
\text { Karan Gund (3), Gund Prang } \\
\text { (4), Vij Pora (19), Sumbal } \\
\text { (NAC) (23), Rakh Shilvat (24), } \\
\text { Gund Nowgam (25), Zal Pora } \\
\text { (27), Gund Bun (29), Ganstan } \\
\text { (34), Gada Khud (38), Odina } \\
\text { (39),Malik Pora (40) and Sadat } \\
\text { Pora (Naid Khai) (41) }\end{array}$ \\
\hline $\begin{array}{l}5.0-6.2 \\
\text { (Very } \\
\text { High) }\end{array}$ & 33 & 25274 & 766 & 10 & $\begin{array}{l}\text { Sarai Danger Pora (15), Gund } \\
\text { Ramzan (22), Nowgam (26), } \\
\text { Rakh Sultan Pora (28), Push } \\
\text { Wari (31),Tanga Pora (32),Kani } \\
\text { Pora (33), Tirgam (35),Gund } \\
\text { Khalil (36) and Najin (37) }\end{array}$ \\
\hline Total & $180^{*}$ & 172396 & 958 & 43 & \\
\hline
\end{tabular}


Table 14 Damaged length $(\mathrm{Km})$ of embankments, road network and canals under different $\mathrm{FHI}$ classes.

\begin{tabular}{lccc}
\hline FHI Class & Embankment & Road & Canal \\
\hline Low & 5.4 & 0.9 & 0.0 \\
Moderate & 7.2 & 4.7 & 4.8 \\
High & 34.8 & 17.1 & 4.7 \\
Very High & 37.0 & 13.3 & 0.0 \\
Total & 84.4 & 36.0 & 9.5 \\
\hline
\end{tabular}

Table 15 Land use/land cover in wetlands and swamps (August 25, 2014).

\begin{tabular}{lcc}
\hline Lu/LC & $\begin{array}{c}\text { Area } \\
\left(\mathrm{Km}^{2}\right)\end{array}$ & $\begin{array}{l}\text { Area in Per } \\
\text { cent }\end{array}$ \\
\hline Built-up & 1 & 2 \\
Plantation/Forest & 5 & 11 \\
Water bodies & 7 & 16 \\
Waste land & 12 & 27 \\
Cropped area & 20 & 44 \\
Total & 45 & 100 \\
\hline
\end{tabular}

